\title{
Thermal Properties, Antimicrobial Activity of Azo Complexes and Ultrastructure Study of Some Affected Bacteria
}

\author{
Abou-Dobara MI ${ }^{1}$, El-Sonbati $\mathrm{AZ}^{2 *}$, Diab MA ${ }^{2}$, El-Bindary $\mathrm{AA}^{2}$ and Sh M Morgan ${ }^{2}$
}

${ }^{1}$ Botany Department, Faculty of Science, Damietta University, Damietta, Egypt

${ }^{2}$ Chemistry Department, Faculty of Science, Damietta University, Damietta, Egypt

\begin{abstract}
A series of copper (II) complexes of bidentate azo rhodanine ligands (HLn) have been synthesized and characterized. The IR spectral and thermogravimetric analysis are used to characterize the isolated complexes. X-ray diffraction patterns show polycrystalline nature for as-synthesized ligand HL2 and its complex. Quantum chemical parameters, absolute hardness, global electrophilicity and additional electronic charge were calculated for HLn. Copper(II) complexes (1-4) are tested against four local bacterial species; namely two Gram positive bacteria (Staphylococcus aureus and Bacillus cereus) and two Gram negative bacteria (Escherichia coli and Klebsiella pneumoniae) and against four local fungal species (Aspergillus niger, Fusarium oxysporium, Penicillium italicum and Alternaria alternata). The tested complexes have good antibacterial activity against Staphylococcus aureus and Escherichia coli and have low antifungal activity against Aspergillus niger, Fusarium oxysporium and Alternaria alternata. We found that the complex (3) is more active than other complexes against Staphylococcus aureus and Escherichia coli as expected from Hammett's substituent coefficients $(\sigma R)$. Ultrastructure studies of the affected Staphylococcus aureus and Escherichia coli confirmed that complex (3) has bactericidal effect.
\end{abstract}

Keywords: Azodye rhodanine derivatives; Antimicrobial activity of $\mathrm{Cu}(\mathrm{II})$ complexes; Transmission electronic micrograph; Thermodynamic parameters; Hammett's substituent coefficients $(\sigma \mathrm{R})$

\section{Introduction}

Azodyes play also an important role in inorganic chemistry, as they easily form stable complexes with most transition metal ions [1-5]. The behavior of azodye complexes have attracted the attention of the bioinorganic chemists, since a number of these complexes are recognized to serve as models for biologically important species [3-7].

Azo compound based on rhodanine, play a central role as chelating agents for a large numbers of metal ions, as they form a stable sixmember ring after complexation with a metal ion and also it could be used as analytical reagents $[8,9]$. The complex-formation equilibria have been reported for several kinds of rhodanine derivatives [10-13]. Potentiometry, conductivity and spectroscopy measurements on the coordination ability biologically important azo derivatives have shown that their complexes are very stable.

Chemical properties of rhodanine and its derivatives are of interest due to coordination capacity also widely prepared and studied several metal complexes of rhodanine azodyes due to their unusual magnetic properties and relevance to biological system $[1,2,14,15]$. Rhodanine and its derivatives are known to possess biological activities such as anticancer, antimiotic, antidiabetic, antibacterial, hypocholesterolemic, antiperlipemic, antiviral and antidiabetic in nature and also reported rhodanine derivatives as Hepatitis C Virus (HCV) protease inhibitor [16-19]. The antimicrobial activity results of rhodanine azo compounds have been compared with the standard antibacterial and antifungal drugs and the results showed that most of these ligands are good antibacterial agents against Bacillus cereus and Staphylococcus aureus and antifungal agents against Aspergillus niger and Fusarium oxysporium [14].

The aim of the present work is the synthesis of $\mathrm{Cu}(\mathrm{II})$ complexes of bidentate azo rhodanine ligands (HLn). The IR spectral and thermogravimetric analysis are used to characterize the purpose of structural elucidation. The activation thermodynamic parameters were calculated using Coats-Redfern and Horowitz-Metzger methods. Study of the antimicrobial activity of $\mathrm{Cu}$ (II) complexes as well as the ultrastructural effect of complex (3) on Staphylococcus aureus and Escherichia coli were recorded.

\section{Experimental}

The structures of the ligands can exist in three tautomeric forms as shown in Figure 1.

\section{Preparation of complexes}

A hot ethanolic solution containing the azodyes (HLn) was mixed with a hot ethanolic solution of $\mathrm{Cu}(\mathrm{OAc})_{2} \cdot \mathrm{H}_{2} \mathrm{O}(1 \mathrm{mmol})$ [4]. The mixture was then refluxed on a water bath for $\sim 10 \mathrm{~h}$ and allowed to cool whereby the solid complexes were separated, which filtered off, washed several times with ethanol, dried and kept in a desiccator over dried $\mathrm{CaCl}_{2}$.

\section{Measurements}

Elemental microanalyses of the separated complexes were determined on Automatic Analyzer CHNS Vario ELIII, Germany. X-ray diffraction analyses of the powder $\mathrm{HL}_{2}$ and its complex $\left[\mathrm{Cu}\left(\mathrm{L}_{2}\right)(\mathrm{OAc})\right.$ $\left.\left(\mathrm{OH}_{2}\right)\right] \cdot 2 \mathrm{H}_{2} \mathrm{O}(4)$ were performed at room temperature by a Philips X-ray diffractometer equipped with utilized monochromatic $\mathrm{Cu}$ Ka radiation

*Corresponding author: El-Sonbati AZ, Chemistry Department, Faculty of Science, Damietta University, Damietta, Egypt, Tel: +201060081581; Fax: +20 572403868; E-mail: elsonbatisch@yahoo.com

Received July 01, 2014; Accepted July 21, 2014; Published July 28, 2014

Citation: Abou-Dobara MI, El-Sonbati AZ, Diab MA, El-Bindary AA, Morgan SM (2014) Thermal Properties, Antimicrobial Activity of Azo Complexes and Ultrastructure Study of Some Affected Bacteria. J Microbial Biochem Technol S3: 006. doi:10.4172/1948-5948.S3-006

Copyright: (c) 2014 Abou-Dobara Ml, et al. This is an open-access article distributed under the terms of the Creative Commons Attribution License, which permits unrestricted use, distribution, and reproduction in any medium, provided the original author and source are credited 


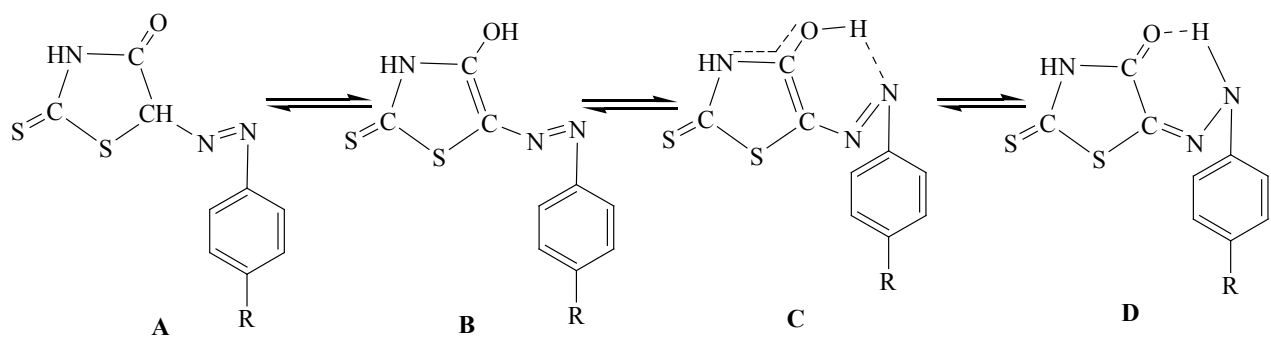<smiles>[R]c1ccc(Oc2[nH]c(=S)sc2N=Nc2cc(N=Nc3sc(=S)[nH]c3O)ccc2[R])cc1</smiles><smiles></smiles>

E<smiles>[R]c1ccc(NN=C2SC(=S)NC2=O)cc1</smiles>

F

$\mathrm{n}=1, \mathrm{R}=\mathrm{OCH}_{3}\left(\mathrm{HL}_{1}\right) ; \mathrm{n}=2, \mathrm{CH}_{3}\left(\mathrm{HL}_{2}\right) ; \mathrm{n}=3, \mathrm{H}\left(\mathrm{HL}_{3}\right) ; \mathrm{n}=4, \mathrm{Cl}\left(\mathrm{HL}_{4}\right) ;$ and $\mathrm{n}=5, \mathrm{NO}_{2}\left(\mathrm{HL}_{5}\right)$

Figure 1: Structure of azodye rhodanine derivatives $\left(\mathrm{HL}_{\mathrm{n}}\right)$.

$(\lambda=1.5418 \AA)$. The X-ray tube voltage and current were $40 \mathrm{kV}$ and 30 $\mathrm{mA}$, respectively. The $1 \mathrm{H}$ NMR spectrum was obtained with a JEOL FX90 Fourier transform spectrometer with DMSO-d6 as the solvent and TMS as an internal reference. The infrared spectra were recorded as $\mathrm{KBr}$ discs using a Perkin-Elmer 1340 spectrophotometer. The magnetic moment of the prepared solid complexes was determined at room temperature using the Gouy's method. Mercury(II) (tetrathiocyanato) cobalt(II), $\left[\mathrm{Hg}\left\{\mathrm{Co}(\mathrm{SCN})_{4}\right\}\right]$, was used for the calibration of the Gouy's tubes. Diamagnetic corrections were calculated from the values given by Selwood [20] and Pascal's constants. Magnetic moments were calculated using the equation, $\mu_{\mathrm{eff}}=2.84\left[\mathrm{~T} \chi_{\mathrm{M}}{ }^{\text {coor }}\right]^{1 / 2}$. Thermogravimetric Analysis (TGA) measurements were investigated using Simultaneous Thermal Analyzer (STA) 6000 with scan rate $15^{\circ} \mathrm{C} / \mathrm{min}$ under dynamic nitrogen atmosphere in the temperature range from 50 to $800^{\circ} \mathrm{C}$.

The molecular structures of the investigated compounds were optimized initially with PM3 semiempirical method so as to speed up the calculations. The resulting optimized structures were fully reoptimized using ab initio Hartree-Fock (HF) [21] with 6-31G basis set. The molecules were built with the Gauss View 3.09 and optimized using Gaussian 03W program [22]. The corresponding geometries were optimized without any geometry constraints for full geometry optimizations. Frequency calculation was executed successfully, and no imaginary frequency was found, indicating minimal energy structures.

\section{Microbiological investigation}

For this investigation the agar well diffusion method was applied [14]. The antibacterial activities of the investigated complexes were tested against two local Gram positive bacterial species (Bacillus cereus and Staphylococcus aureus) and two local Gram negative bacterial species (Escherichia coli and Klebsiella pneumoniae) on nutrient agar medium. Also, the antifungal activities were tested against four local fungal species (Aspergillus niger, Alternaria alternata, Penicillium 


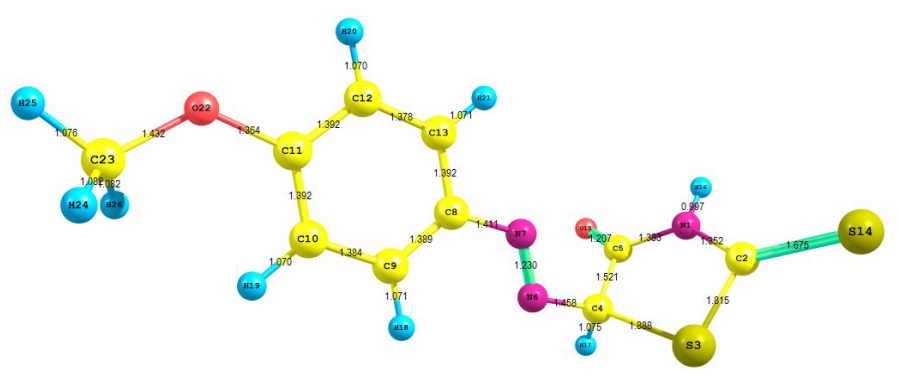

$\mathrm{HL}_{1}$

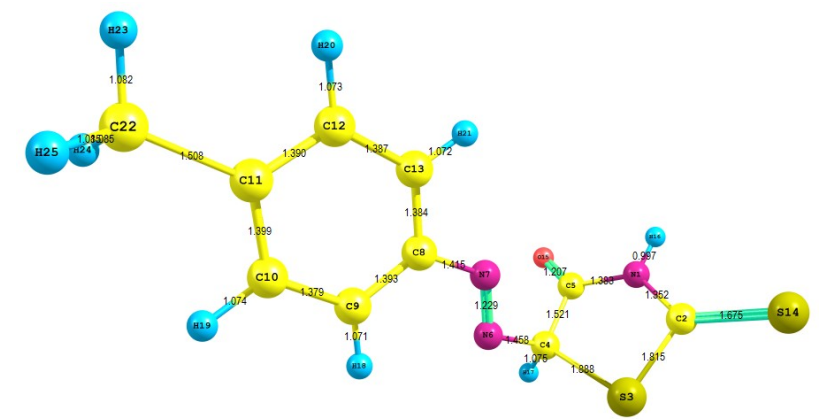

Hг.

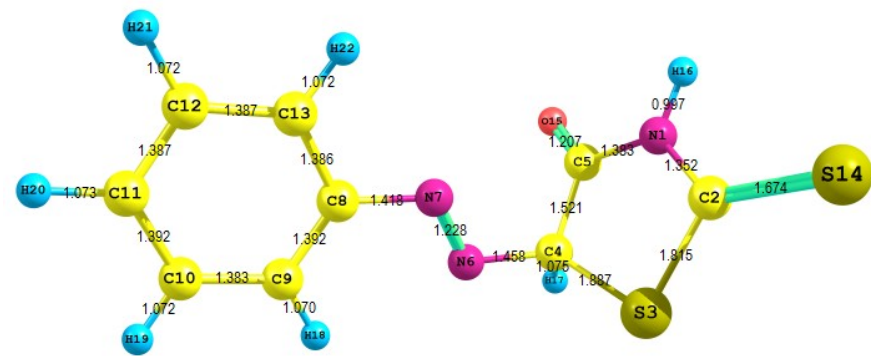

$\mathrm{HL}_{3}$

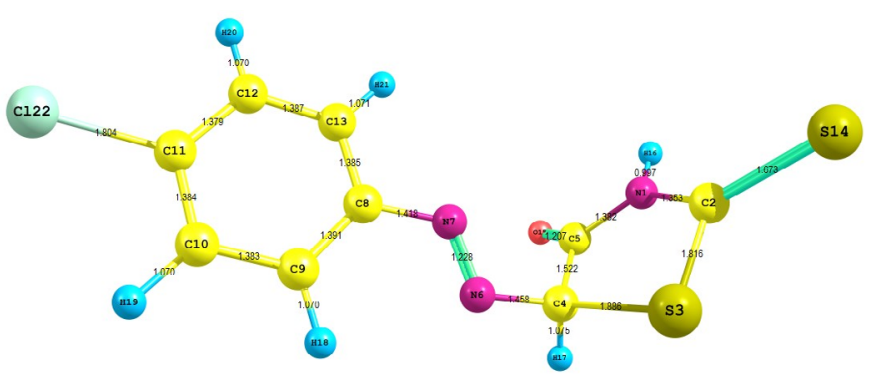

$\mathrm{HL}_{4}$

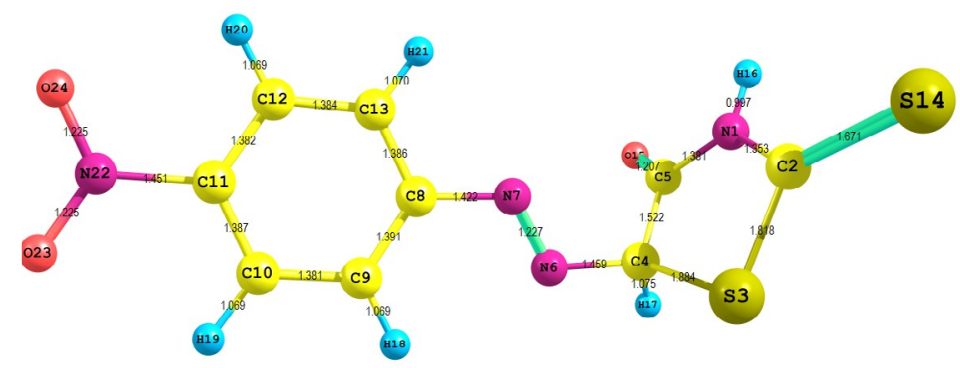

$\mathrm{HL}_{5}$

Figure 2: Geometry optimized structures of the investigated ligands $\left(\mathrm{HL}_{\mathrm{n}}\right)$. 
italicum and Fusarium oxysporium) on DOX agar medium. The concentrations of each solution were $50 \mu \mathrm{g} / \mathrm{ml}, 100 \mu \mathrm{lg} / \mathrm{ml}$ and $150 \mu \mathrm{g} /$ $\mathrm{ml}$. By using a sterile cork borer (10 mm diameter), wells were made in agar medium plates previously seeded with the test microorganism. $200 \mu \mathrm{l}$ of each compound was applied in each well. The agar plates were kept at $4^{\circ} \mathrm{C}$ for at least $30 \mathrm{~min}$. to allow the diffusion of the compound to agar medium. The plates were then incubated at $37^{\circ} \mathrm{C}$ or $30^{\circ} \mathrm{C}$ for bacteria and fungi, respectively. The diameters of inhibition zone were determined after $24 \mathrm{~h}$ and 7 days for bacteria and fungi, respectively. Penicillin and miconazole were used as reference substances against bacteria and fungi, respectively.

For electron microscopic study, 18 hour of Staphylococcus aureus and Escherichia coli were subjected to $150 \mu \mathrm{g} / \mathrm{ml}$ of complex (3) for 2 hours. Also, normal bacteria and DMF treated bacteria were included. After that, bacterial cells were centrifuged and washed with distilled water. Bacteria were fixed with formalin-glutaraldehyde fixative (4F1G) in $0.1 \mathrm{M}$ phosphate buffer $\mathrm{pH}$ 7.4. After rinsing in the buffer, samples were post-fixed in $2 \% \mathrm{OsO}_{4}$ for $2 \mathrm{~h}$ at $4^{\circ} \mathrm{C}$ in the same buffer. The cells were washed and dehydrated at $4^{\circ} \mathrm{C}$ through a graded series of ethanol. Cells were then treated with propylene oxide solution and embedded in a mixture of 1:1 of Epon-Araldite for $1 \mathrm{~h}$. Polymerization was done in the oven at $65^{\circ} \mathrm{C}$ for $24 \mathrm{~h}$. Ultrathin sections $(50 \mu \mathrm{m})$ were cut on ultratome (Model LKB), then mounted on copper grids, double stained with uranyl acetate and lead citrate and investigated on a JEOL 100CX TEM.

\section{Morphometric analyses}

Morphometric analyses were achieved by using UTHSCSA Image tool software for windows version 3 .

\section{Statistical analysis}

All the data of morphometric analysis was expressed as Mean \pm SE. The statistical significance was evaluated by ANOVA using SPSS Version 10 and the individual comparison were obtained by LSD method at 0.05 significant levels.

\section{Results and Discussion}

\section{Structure of the ligand}

The geometrical structures of the investigated ligands (HLn) with the optimized bond lengths are shown in Figure 2. The optimized molecular structures, the highest occupied molecular orbital (HOMO) and the lowest unoccupied molecular orbital (LUMO) of the investigated ligands (HLn) are shown in Figure 3.

Quantum chemical parameters of ligands are obtained from calculations such as energy of the highest occupied molecular orbital, EHOMO, energy of the lowest unoccupied molecular orbital, ELUMO, energy gap, $\Delta \mathrm{E}$, and dipole moment, $\mu$, as presented in Table 1 . Additional parameters such as separation energies, $\Delta \mathrm{E}$, absolute electronegativities, $\chi$, chemical potentials, $P \mathrm{i}$, absolute hardness, $\eta$, absolute softness, $\sigma$, global electrophilicity, $\omega$, global softness, $S$, and additional electronic charge, $\Delta \mathrm{Nmax}$, have been calculated according to the following equations $[4,23]$ :

$$
\begin{aligned}
& \Delta E=E_{\text {LUMO }}-E_{\text {HOMO }} \\
& \chi=\frac{-\left(E_{\text {HOMO }}+E_{\text {LUMO }}\right)}{2}
\end{aligned}
$$

(HiL)
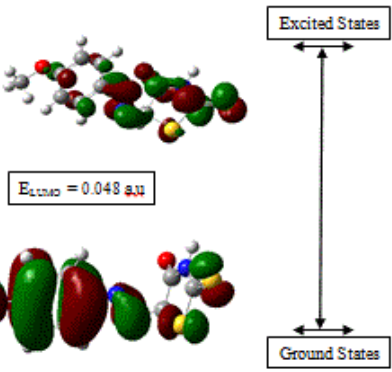

(HL:)

$E_{\text {tens }}=0.048$ s.,
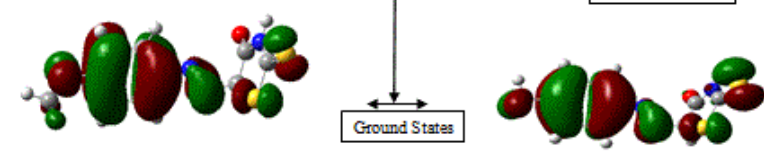

$E_{\text {mבMo }}=-0.327$ a.

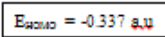

$\left(\mathrm{HL}_{3}\right)$
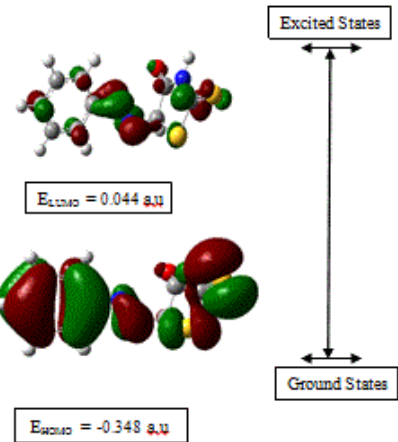

(HL.)

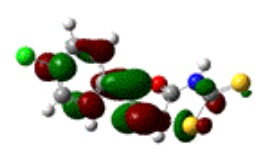

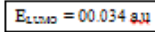

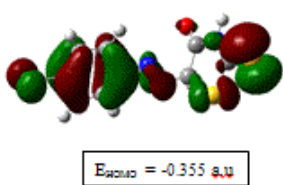

(HLs)

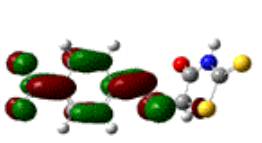

Excited States

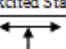

$\mathrm{E}_{4 \tan }=-0.004$ 9.2.

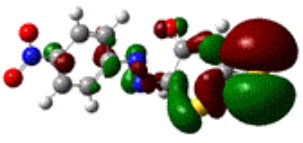

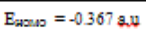

Figure 3: $\mathrm{HOMO}$ and LUMO molecular orbital of ligands $\left(\mathrm{HL}_{\mathrm{n}}\right)$.

$$
\begin{aligned}
& \eta=\frac{E_{L U M O}-E_{\text {HOMO }}}{2} \\
& \sigma=\frac{1}{\eta}, P i=-\chi \\
& S=\frac{1}{2 \eta}, \omega=\frac{P i^{2}}{2 \eta} \\
& \Delta N_{\max }=-\frac{P i}{\eta}
\end{aligned}
$$

The lower value of energy gap $(\Delta \mathrm{E})$, indicates the more stable ligand and highly reactive than the other ligands [24]. The concepts of the parameters $\chi$ and $P i$ are related to each other. The inverse of the global hardness is designated as the softness [4]. From the obtained data (Table 1) we can deduced that:

Absolute hardness $(\eta)$ and softness $(\sigma)$ are important properties to measure the molecular stability and reactivity. The values of $\Delta \mathrm{N}_{\max }$ for 
Citation: Abou-Dobara MI, El-Sonbati AZ, Diab MA, El-Bindary AA, Morgan SM (2014) Thermal Properties, Antimicrobial Activity of Azo Complexes and Ultrastructure Study of Some Affected Bacteria. J Microbial Biochem Technol S3: 006. doi:10.4172/1948-5948.S3-006

Page 5 of 13

\begin{tabular}{|c|c|c|c|c|c|c|c|c|c|c|c|c|}
\hline Compound & $\mathrm{E}_{\text {номо }}(\mathrm{a} . \mathrm{u})$ & $\mathrm{E}_{\text {LUMo }}$ (a.u) & $\Delta E($ a.u) & $\mu(D)$ & T.E(a.u) & X (a.u) & n (a.u) & $\sigma(a . u)^{-1}$ & Pi (a.u) & $S(a . u)^{-1}$ & $\omega \quad$ (a.u) & $\Delta \boldsymbol{N}_{\max }$ \\
\hline $\mathrm{HL}_{1}$ & -0.327 & 0.048 & 0.375 & 5.358 & -1491.580 & 0.139 & 0.188 & 5.333 & -0.139 & 2.667 & 0.052 & 0.744 \\
\hline $\mathrm{HL}_{2}$ & -0.337 & 0.047 & 0.384 & 4.554 & -1416.775 & 0.145 & 0.192 & 5.208 & -0.145 & 2.604 & 0.055 & 0.755 \\
\hline $\mathrm{HL}_{3}$ & -0.348 & 0.044 & 0.432 & 3.950 & -1377.752 & 0.152 & 0.196 & 5.102 & -0.152 & 2.551 & 0.059 & 0.776 \\
\hline $\mathrm{HL}_{4}$ & -0.355 & 0.034 & 0.389 & 2.001 & -1836.627 & 0.161 & 0.195 & 5.141 & -0.161 & 2.571 & 0.066 & 0.825 \\
\hline $\mathrm{HL}_{5}$ & -0.367 & -0.004 & 0.363 & 3.712 & -1581.099 & 0.186 & 0.182 & 5.509 & -0.186 & 2.755 & 0.095 & 1.022 \\
\hline
\end{tabular}

Table 1: The calculated quantum chemical parameters of the investigated ligands $\left(\mathrm{HL}_{\mathrm{n}}\right)$.

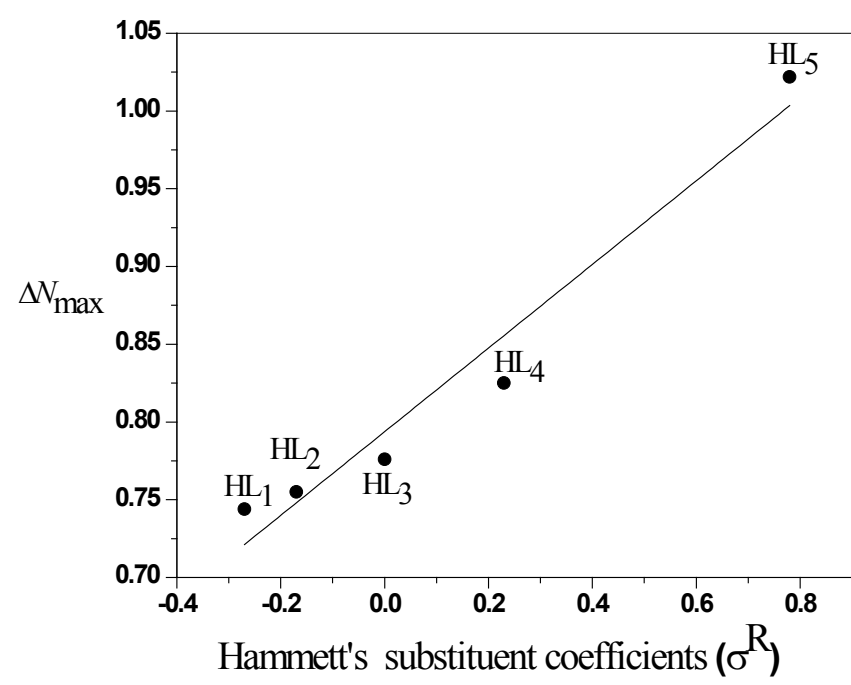

Figure 4: The relation between Hammett's substituent coefficients $\left(\sigma^{R}\right)$ versus $\Delta N_{\max }$ for ligands $\left(\mathrm{HL}_{\mathrm{n}}\right)$

$\mathrm{HL}_{\mathrm{n}}$ are calculated and found to be in the range 0.744-1.022 dependent on the nature of the substituent. They tend to the increase according to the following order $p-\left(\mathrm{OCH}_{3}<\mathrm{CH}_{3}<\mathrm{H}<\mathrm{Cl}<\mathrm{NO}_{2}\right)$. This is in accordance with that expected from Hammett's constant coefficients $\left(\sigma^{\mathrm{R}}\right)$ as shown in Figure 4.

\section{${ }^{1}$ H NMR spectra}

The ${ }^{1} \mathrm{H}$ NMR spectra of azodye rhodanine derivatives are in agreement with the proposed structures. Signal for $\mathrm{CH}(\sim 4.42 \mathrm{ppm})$, favoring formation of an intramolecular hydrogen bond with the$\mathrm{N}=\mathrm{N}$-(azodye) group. Electron-withdrawing substituents reduce the intramolecular hydrogen bond as indicated by the marked shift of the hydroxyl signal to higher field in the $p-\mathrm{NO}_{2}$ and $p$ - $\mathrm{Cl}$ compounds. Electron-donating substituents give the opposite effect, arising from the increasing basicity of the azo-nitrogen. The broad signals assigned to the $\mathrm{OH}$ protons at $\sim 11.36-11.88 \mathrm{ppm}$ are not affected by dilution.

\section{Infrared spectra of ligands $\left(\mathrm{HL}_{\mathrm{n}}\right)$}

The infrared spectra of ligands $\left(\mathrm{HL}_{\mathrm{n}}\right)$ give two bands at $\sim 3200-3040$ $\mathrm{cm}^{-1}$ due to asymmetric and symmetric stretching vibrations of $\mathrm{N}-\mathrm{H}$ group and intramolecular hydrogen bonding $\mathrm{NH}$... O systems (Figure 1D), respectively.

The broad absorption band located at $23400 \mathrm{~cm}^{-1}$ is assigned to $v \mathrm{OH}$. The low frequency bands indicate that the hydroxy hydrogen atom is involved in keto $\leftrightarrow$ enol $(A \leftrightarrow B)$ tautomerism through hydrogen bonding (Figure 1C).

The infrared spectra of ligands shows medium broad band located at $\sim 3460 \mathrm{~cm}^{-1}$ due the stretching vibration of some sort of hydrogen of hydrogen bonding. El-Sonbati et al. [4,25-27] made detailed studies for the different types of hydrogen bonding which are favorable to exist in the molecule under investigation:

1) Intramolecular hydrogen bond between the nitrogen atom of the $-\mathrm{N}=\mathrm{N}$ - system and hydrogen atom of the hydroxy hydrogen atom (Figure 1C). This is evident by the presence of a broad band centered at $3460 \mathrm{~cm}^{-1}$.

2) Hydrogen bonding of the $\mathrm{OH} . . \mathrm{N}$ type between the hydroxy hydrogen atom and the N-ph group (Figure 1C).

3) Intermolecular hydrogen bonding is possible forming cyclic dimer through $\mathrm{NH} \ldots \mathrm{O}=\mathrm{C}(\mathrm{G}), \mathrm{OH} \ldots \mathrm{N}=\mathrm{N}(\mathrm{F})$ or $\mathrm{OH} \ldots \mathrm{OH}(\mathrm{E})$ (Figure 1).

\section{Infrared spectra of complexes and nature of coordination}

The bonding of the metal ion to the ligand can be clarified by comparing the IR-spectra of the complexes with those of the ligands.

In the IR spectra of all metal complexes (1-4) a number of changes are observed:

1) The appearance of a new bands around $\sim 3380 \mathrm{~cm}^{-1}$ and two sharp bands at $\sim 715$ and $420 \mathrm{~cm}^{-1}$, the latter two can be assigned to the wagging and rocking modes of vibration of the water molecule, respectively, [28] in the prepared complexes (1-4) may be taken as a strong evidence for the presence of coordinated water.

2) The $\mathrm{N}=\mathrm{N}$ stretching frequency of the azo groups is shifted to lower frequency by $\sim 15-25 \mathrm{~cm}^{-1}$ due to the involvement of one of the azo nitrogen atoms in coordination with metal ion [2-4]. This lowering of frequency can be explained by the transfer of electrons from nitrogen atom to the $\mathrm{Cu}(\mathrm{II})$ ion due to coordination.

3) In solution and in the presence of $\mathrm{Cu}(\mathrm{II})$ ions these compounds exist in a tautomerism equilibrium [4,5] $A \leftrightarrow B \leftrightarrow C$ (Figure 1). The tautomeric form $(\mathrm{C})$ react with metal ions by loss of phenolic proton as mononegative chelating agents producing of $\mathrm{CO} / \mathrm{OH}$ mode of the free ligands $[4,29]$.

4) Furthermore, the bands in the regions $545-560$ and $420-428$ $\mathrm{cm}^{-1}$ can be assigned to the stretching modes of the metal to ligand bonds, $v(\mathrm{Cu}-\mathrm{O})$ and $v(\mathrm{Cu}-\mathrm{N})$ for 1:1 (M:L) complexes, respectively, [4]. Absence of $v(M-S)$ band in the far IR spectra gives added evidence for the non-participation of ring sulphur atom in bond formation.

On the basis of all these data, the molecular structure of the $\mathrm{Cu}(\mathrm{II})$ complexes could be suggested based on :

i) the presence of anion, ii) the disappearance of $\mathrm{C}=\mathrm{O}$, iii) the coordination of azo-group iv) the presence of water.

According to the structure shows in Figure 5 and analytical data in Table 2, the ligand (HLn) takes its usual anionic form (Ln) to chelate $\mathrm{Cu}$ (II) through $\mathrm{N}$ - of azo group with enol group (Figure 1C) as the potential binding sites. The analytical data agree satisfactory with the expected formulae represented as given in Figure 5. 
Magnetic measurements and electronic spectra were conducted in order to obtain information about the geometry of the complexes. The magnetic susceptibility values (1.83-1.87 B.M.) which was consistent with presence of a single unpaired electron [4]. This behavior suggest square planar geometry for the $\mathrm{Cu}(\mathrm{II})$ complexes [4].

The analytical data of ligands and their complexes agree satisfactory with the expected formulae represented as given in structures (Figures 1 and 5).

\section{X-ray diffraction}

The X-ray diffraction, XRD, patterns of the as-synthesized ligand

\begin{tabular}{|c|c|c|c|c|c|c|}
\hline \multirow[t]{2}{*}{ Complex } & \multirow{2}{*}{$\begin{array}{l}\mu_{\text {eff }} \\
\text { B.M. }\end{array}$} & \multicolumn{5}{|c|}{ Calc. (Exp.)\% } \\
\hline & & C & $\mathbf{H}$ & $\mathbf{N}$ & $\mathbf{S}$ & M \\
\hline $\begin{array}{l}{\left[\mathrm{Cu}\left(\mathrm{L}_{1}\right)(\mathrm{OAc})\left(\mathrm{OH}_{2}\right)\right] \cdot 2 \mathrm{H}_{2} \mathrm{O}} \\
\text { (1) }\end{array}$ & 1.83 & $\begin{array}{c}32.54 \\
(32.47)\end{array}$ & $\begin{array}{c}3.84 \\
(3.72)\end{array}$ & $\begin{array}{c}9.49 \\
(9.13)\end{array}$ & $\begin{array}{c}14.46 \\
(14.07)\end{array}$ & $\begin{array}{c}14.36 \\
(14.06)\end{array}$ \\
\hline $\begin{array}{l}{\left[\mathrm{Cu}\left(\mathrm{L}_{3}\right)(\mathrm{OAc})\left(\mathrm{OH}_{2}\right)\right] \cdot 2 \mathrm{H}_{2} \mathrm{O}} \\
(2)\end{array}$ & 1.85 & $\begin{array}{c}33.76 \\
(33.60)\end{array}$ & $\begin{array}{c}3.99 \\
(3.82)\end{array}$ & $\begin{array}{c}9.85 \\
(9.46)\end{array}$ & $\begin{array}{c}15.01 \\
(14.86)\end{array}$ & $\begin{array}{c}14.90 \\
(14.72)\end{array}$ \\
\hline $\begin{array}{l}{\left[\mathrm{Cu}\left(\mathrm{L}_{5}\right)(\mathrm{OAc})\left(\mathrm{OH}_{2}\right)\right] \cdot 2 \mathrm{H}_{2} \mathrm{O}} \\
\text { (3) }\end{array}$ & 1.87 & $\begin{array}{c}32.00 \\
(31.86)\end{array}$ & $\begin{array}{c}3.64 \\
(3.44)\end{array}$ & $\begin{array}{l}10.18 \\
(9.87)\end{array}$ & $\begin{array}{c}15.51 \\
(15.27)\end{array}$ & $\begin{array}{c}15.40 \\
(15.17)\end{array}$ \\
\hline $\begin{array}{l}{\left[\mathrm{Cu}\left(\mathrm{L}_{2}\right)(\mathrm{OAc})\left(\mathrm{OH}_{2}\right)\right] \cdot 2 \mathrm{H}_{2} \mathrm{O}} \\
\text { (4) }\end{array}$ & 1.84 & $\begin{array}{c}28.51 \\
(28.40)\end{array}$ & $\begin{array}{c}3.02 \\
(2.89)\end{array}$ & $\begin{array}{c}9.07 \\
(8.78)\end{array}$ & $\begin{array}{c}13.82 \\
(13.65)\end{array}$ & $\begin{array}{c}13.72 \\
(13.47)\end{array}$ \\
\hline
\end{tabular}

Table 2: Analytical and magnetic moments of $\mathrm{Cu}(\mathrm{II})$ complexes.

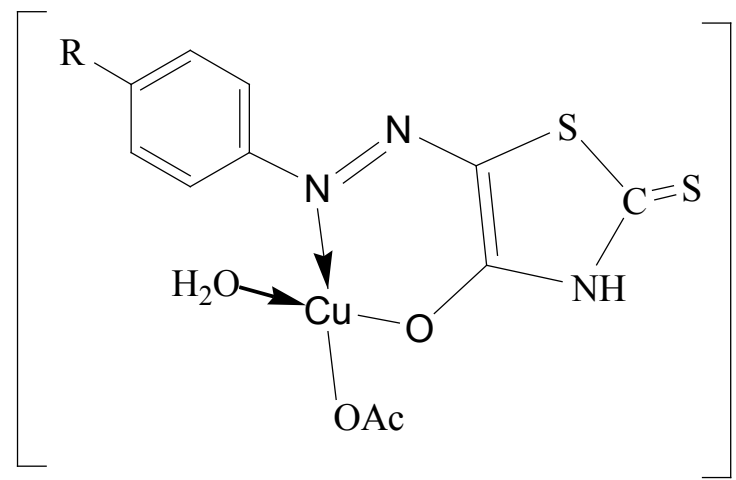

Figure 5: The structure of the $\mathrm{Cu}(\mathrm{II})$ complexes.

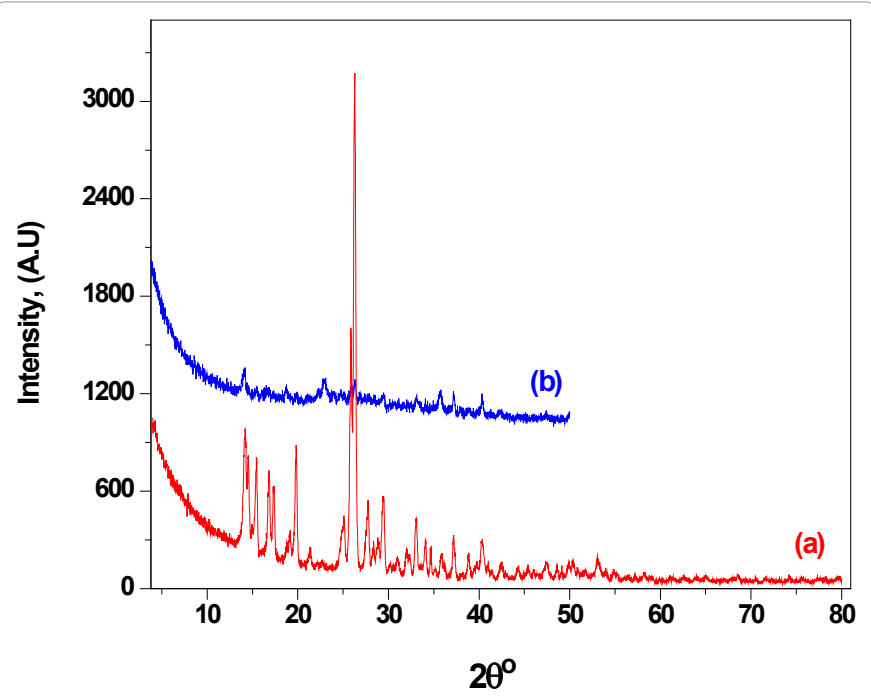

Figure 6: X-ray diffraction patterns for a) $\mathrm{HL}_{2}$ and b) $\left[\mathrm{Cu}\left(\mathrm{L}_{2}\right)(\mathrm{OAc})\left(\mathrm{OH}_{2}\right)\right] \cdot 2 \mathrm{H}_{2} \mathrm{O}$ powder forms.

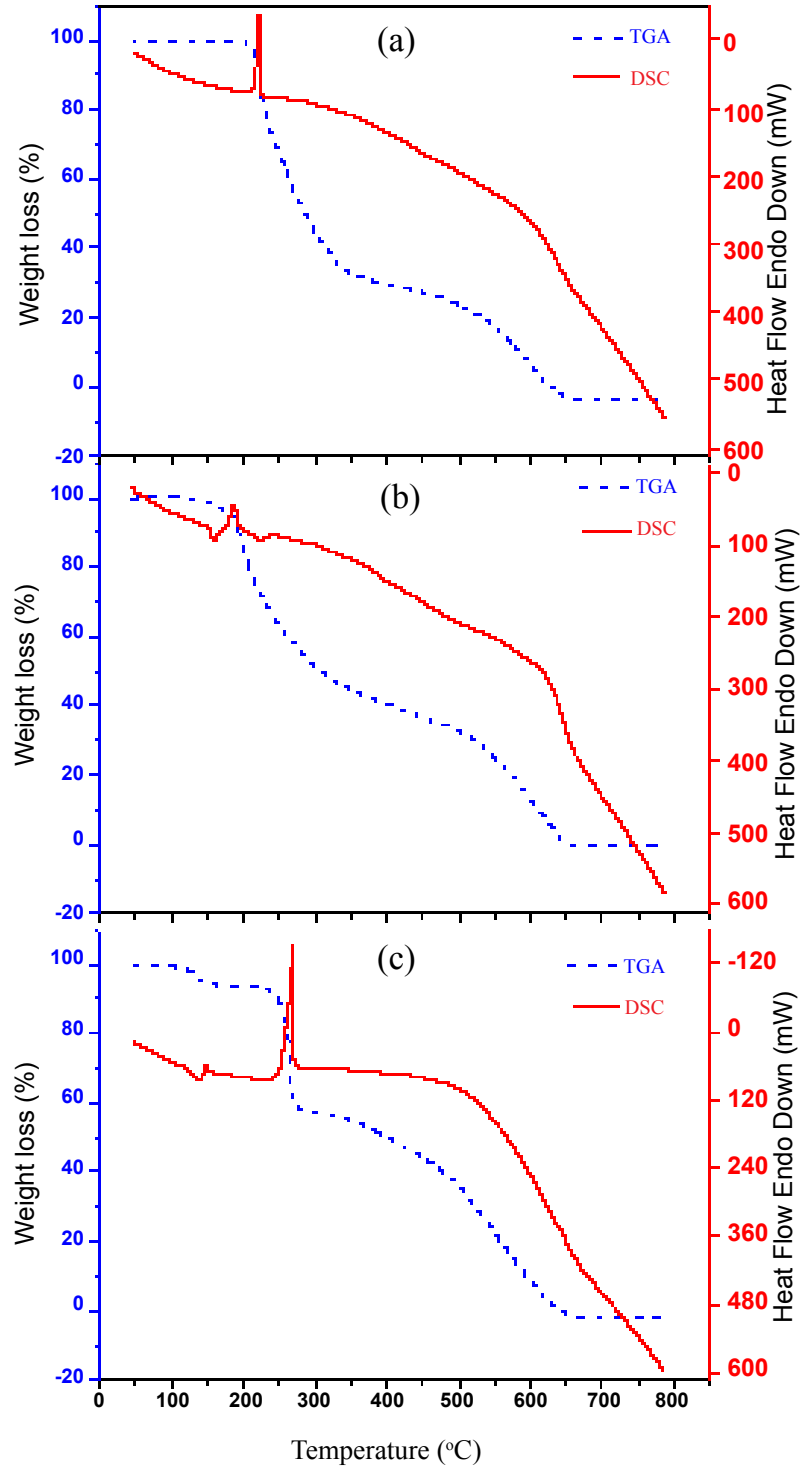

Figure 7: TGA and DSC thermo graphs for (a) $\mathrm{HL}_{1}$, (b) $\mathrm{HL}_{3}$ and (c) $\mathrm{HL}_{5}$.

HL2 and complex (4) powder forms are shown in Figure 6. Many peaks are observed which indicate the polycrystalline nature of the assynthesized ligand HL2 and complex (4). The average crystallite size $(\xi)$ can be determined using by Debye-Scherrer equation [30-32]:

$$
\xi=\frac{K \lambda}{\beta_{1 / 2} \cos \theta}
$$

where $\lambda$ is $\mathrm{X}$-ray of wavelength $(1.541874 \AA$ ), $\mathrm{K}$ is constant taken as 0.95 for azo compounds [31], $\beta^{1 / 2}$ is the full width at half maximum height and $\theta$ is Bragg angle. The dislocation density, $\delta$, is the number of dislocation lines per unit area of the crystal. The value of $\delta$ is related to the average particle diameter $(\xi)$ by the relation $[32,33]$ :

$$
\delta=\frac{1}{\xi^{2}}
$$

The values of $\xi$ are calculated and found to be 283 and $180 \mathrm{~nm}$ for 
Citation: Abou-Dobara MI, El-Sonbati AZ, Diab MA, El-Bindary AA, Morgan SM (2014) Thermal Properties, Antimicrobial Activity of Azo Complexes and Ultrastructure Study of Some Affected Bacteria. J Microbial Biochem Technol S3: 006. doi:10.4172/1948-5948.S3-006

Page 7 of 13

\begin{tabular}{|c|c|c|c|c|c|c|c|}
\hline \multirow[t]{2}{*}{ Compound } & \multicolumn{2}{|c|}{ First stage } & \multicolumn{2}{|c|}{ Second stage } & \multicolumn{2}{|c|}{ Third stage } & \multirow{2}{*}{$\begin{array}{l}\text { Remaining Weight } \\
\text { after } 650^{\circ} \mathrm{C}\end{array}$} \\
\hline & Temperature $\left({ }^{\circ} \mathrm{C}\right)$ & Weight loss (\%) & Temperature $\left({ }^{\circ} \mathrm{C}\right)$ & Weight loss (\%) & Temperature $\left({ }^{\circ} \mathrm{C}\right)$ & Weight loss (\%) & \\
\hline $\mathrm{HL}_{1}$ & 200 & 61.9 & 320 & 38.1 & - & - & Ash \\
\hline $\mathrm{HL}_{3}$ & 145 & 59.8 & 400 & 39.9 & - & - & Ash \\
\hline $\mathrm{HL}_{5}$ & 112 & 5.4 & 225 & 33.6 & 284 & 58.7 & Ash \\
\hline
\end{tabular}

Table 3: Weight losses percentage of $\mathrm{HL}_{1}, \mathrm{HL}_{3}$ and $\mathrm{HL}_{5}$.

\begin{tabular}{|c|c|c|c|}
\hline Complex ${ }^{a}$ & Temp. range $\left({ }^{\circ} \mathrm{C}\right)$ & Found mass loss (calc.) \% & Assignment \\
\hline \multirow[t]{4}{*}{ (1) } & $45-189$ & $7.24(8.13)$ & Loss of two water molecules in outside of the coordination sphere. \\
\hline & $189-331$ & $16.67(17.39)$ & Loss of one coordinated water molecule and one coordinated acetate group. \\
\hline & $331-506$ & $24.43(24.17)$ & Further decomposition of a part of the ligand $\left(\mathrm{C}_{7} \mathrm{H}_{7} \mathrm{O}\right)$. \\
\hline & $506-709$ & $14.38(14.46)$ & Evolution of $\mathrm{SO}_{2}$ gas leaving $\mathrm{CuO}$ residue with contaminated carbon atoms. \\
\hline \multirow[t]{5}{*}{ (2) } & $45-178$ & $7.91(8.73)$ & Loss of two water molecules in outside of the coordination sphere. \\
\hline & $178-273$ & $18.61(18.66)$ & Loss of one coordinated water molecule and one coordinated acetate group. \\
\hline & $273-514$ & $18.06(18.42)$ & Further decomposition of a part of the ligand $\left(\mathrm{C}_{6} \mathrm{H}_{4}\right)$. \\
\hline & $514-560$ & $6.64(6.79)$ & Evolution of $\mathrm{N}_{2}$ gas. \\
\hline & $560-640$ & $15.43(15.51)$ & Evolution of $\mathrm{SO}_{2}$ gas leaving $\mathrm{CuO}$ residue with contaminated carbon atoms. \\
\hline \multirow[t]{5}{*}{ (3) } & $45-189$ & $4.15(7.87)$ & Loss of two water molecules in outside of the coordination sphere. \\
\hline & $189-288$ & $16.72(16.83)$ & Loss of one coordinated water molecule and one coordinated acetate group. \\
\hline & $288-400$ & $10.46(10.05)$ & Evolution of $\mathrm{NO}_{2}$ gas. \\
\hline & $400-592$ & $13.72(13.98)$ & Evolution of $\mathrm{SO}_{2}$ gas. \\
\hline & $592-670$ & $22.44(22.73)$ & Decomposition of a part of the ligand $\left(\mathrm{C}_{6} \mathrm{H}_{4} \mathrm{~N}_{2}\right)$ leaving $\mathrm{CuO}$ residue with contaminated carbon atoms. \\
\hline \multirow[t]{4}{*}{ (4) } & 40-189 & $5.22(8.44)$ & Loss of two water molecules in outside of the coordination sphere. \\
\hline & $189-316$ & $18.00(18.05)$ & Loss of one coordinated water molecule and one coordinated acetate group. \\
\hline & $316-533$ & $20.47(21.33)$ & Further decomposition of a part of the ligand $\left(\mathrm{C}_{7} \mathrm{H}_{7}\right)$. \\
\hline & $533-670$ & $15.45(15.00)$ & Evolution of $\mathrm{SO}_{2}$ gas and $\mathrm{CuO}$ residue with contaminated carbon atoms. \\
\hline
\end{tabular}

aNumbers as given in Table 2

Table 4: Thermal analyses data of the Cu(II) complexes.

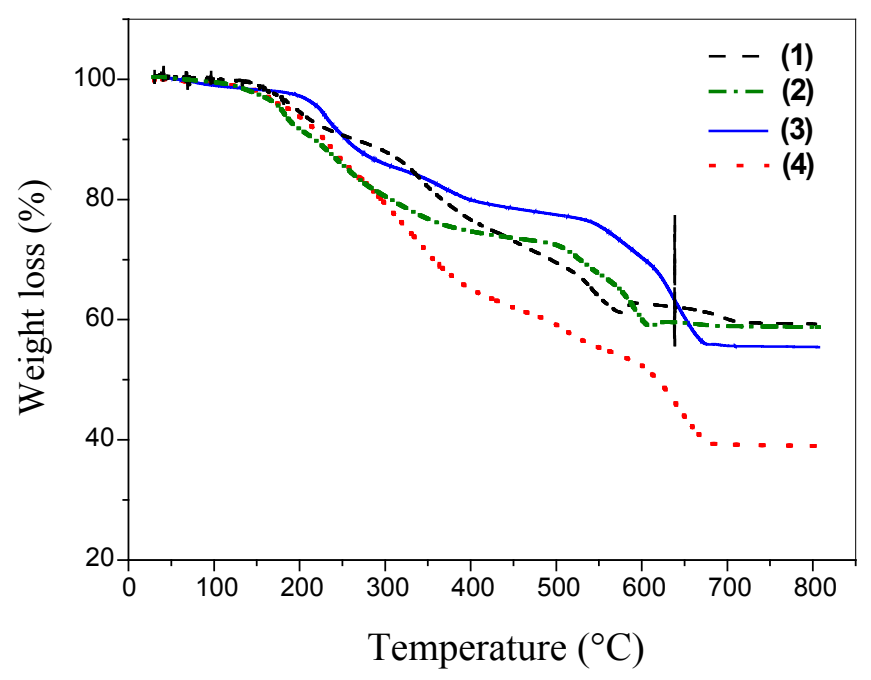

Figure 8: TGA curves for $\mathrm{Cu}(\mathrm{II})$ complexes.

$\mathrm{HL}_{2}$ and complex (4), respectively. The values of $\delta$ are $1.25 \times 10^{-5}$ and $3.09 \times 10^{-5} \mathrm{~nm}^{-2}$ for $\mathrm{HL}_{2}$ and complex (4), respectively.

\section{Thermal analyses}

Thermogravimetric analysis of ligands $\left(\mathrm{HL}_{\mathbf{n}}\right)$ : The Thermogravimetric Analysis (TGA) data of ligands $\left(\mathrm{HL}_{\mathrm{n}}\right)$ is represented in Table 3. The Differential Scanning Calorimetry (DSC) curves exhibit a series of thermal changes during the increase of temperature. The TGA and DSC curves for $\mathrm{HL}_{\mathrm{n}}$ (where $\mathrm{n}=1,3$ and 5) are shown in Figure 7.

The DSC curves for $\mathrm{HL}_{\mathrm{n}}$ are shown in Figure $7(\mathrm{a}-\mathrm{c})$. For the $\mathrm{HL}_{1}$ ligand the recorded DSC curve show only one exothermic peak at $220^{\circ} \mathrm{C}$. Simultaneously, the recorded DSC curve of the $\mathrm{HL}_{3}$ ligand show two exothermic and endothermic peaks at $190^{\circ} \mathrm{C}$ and $180^{\circ} \mathrm{C}$, respectively, while the recorded DSC curve of the $\mathrm{HL}_{5}$ ligand show two exothermic and endothermic peaks at $245^{\circ} \mathrm{C}$ and $120^{\circ} \mathrm{C}$, respectively [34].

Thermogravimetric analysis of complexes: The thermal analysis of the $\mathrm{Cu}(\mathrm{II})$ complexes was studied by TGA technique to give more information on the structure of the investigated complexes. The TGA data for the $\left[\mathrm{CuL}_{n}(\mathrm{OAc})\left(\mathrm{OH}_{2}\right)\right] \cdot 2 \mathrm{H}_{2} \mathrm{O}$ complexes $(\mathrm{n}=1,2,3$, and 5) are summarized in Table 4. It can be seen that the TGA curves of the complexes $\left[\mathrm{CuL}(\mathrm{OAc})\left(\mathrm{OH}_{2}\right)\right] \cdot 2 \mathrm{H}_{2} \mathrm{O}$ complexes, pointed to that the dehydration process of two lattice occurs within the temperature range $\sim 45-189^{\circ} \mathrm{C}$. However, the dehydration of one coordinated $\mathrm{H}_{2} \mathrm{O}$ and one acetate group take place in one step and in the temperature range $\sim 189-331^{\circ} \mathrm{C}$ as shown in Figure 8.

\section{Calculation of activation thermodynamic parameters}

The thermodynamic activation parameters of decomposition processes of complexes namely activation energy $\left(\mathrm{E}_{\mathrm{a}}\right)$, enthalpy $\left(\Delta H^{*}\right)$, entropy $\left(\Delta S^{*}\right)$, and Gibbs free energy change of the decomposition $\left(\Delta G^{*}\right)$ are evaluated graphically by employing the Coast-Redfern [35] and Horowitz-Metzger [36] methods.

Coast-Redfern equation:

The Coast-Redfern equation, which is a typical integral method, can represent as:

$$
\int_{0}^{a} \frac{d x}{(1-\alpha)^{n}}=\frac{A}{\phi} \int_{T_{1}}^{T} 2 \exp \left(-\frac{E_{a}}{R T}\right) d t
$$


Citation: Abou-Dobara MI, El-Sonbati AZ, Diab MA, El-Bindary AA, Morgan SM (2014) Thermal Properties, Antimicrobial Activity of Azo Complexes and Ultrastructure Study of Some Affected Bacteria. J Microbial Biochem Technol S3: 006. doi:10.4172/1948-5948.S3-006

Page 8 of 13

For convenience of integration, the lower limit T1 usually taken as zero. This equation on integration gives:

$$
\ln \left[-\frac{\ln (1-\alpha)}{T^{2}}\right]=-\frac{E_{a}}{R T}+\ln \left[\frac{A R}{\phi E_{a}}\right]
$$

A plot of left-hand side (LHS) against $1 / \mathrm{T}$. $\mathrm{E}_{\mathrm{a}}$ is the energy of activation and calculated from the slop and $\mathrm{A}$ in $\left(\mathrm{s}^{-1}\right)$ from the intercept value. The entropy of activation $\Delta S^{*}$ in $\left(\mathrm{J} \mathrm{K}^{-1} \mathrm{~mol}^{-1}\right)$ calculated by using the equation:

$$
\Delta S^{*}=2.303\left[\log \left(\frac{A h}{k_{B} T_{s}}\right)\right] \mathrm{R}
$$

where $k_{B}$ is the Boltzmann constant, $h$ is the Plank's constant and $T_{s}$ is the TG peak temperature.

Horowitz-Metzger equation:

The Horowitz-Metzger equation is an illustrative of the approximation methods. These authors derived the relation:

$$
\log \left[\frac{1-(1-\alpha)^{1-n}}{1-n}\right]=\frac{E_{a} \theta}{2.303 R T_{s}^{2}} \text {, for } \mathrm{n \#} 1
$$

when $n=1$, the LHS of equation 10 would be $\log [-\log (1-\alpha)]$. For a first order kinetic process, the Horowitz-Metzger equation may write in the form:

$$
\log \left[\log \left(\frac{W_{\alpha}}{W \gamma}\right)\right]=\frac{E_{a} \theta}{2.303 R T_{s}^{2}}-\log 2.303
$$

where $\theta=\mathrm{T}-\mathrm{T}, w_{\gamma}=w_{\alpha}-w, w_{\alpha}=$ mass loss at the completion reaction; $w=$ mass loss up to time t. The relation between $\log \left[\log \left(w_{\alpha} / w_{\gamma}\right)\right]$ and $\theta$ was found linear from the slope of which $\mathrm{E}_{\mathrm{a}}$ was calculated. The preexponential factor, $\mathrm{A}$, calculated from equation:

$$
\frac{E_{a}}{R T_{s}^{2}}=\frac{A}{\left[\phi \exp \left(-\frac{E_{a}}{R T_{s}}\right)\right]}
$$

The entropy of activation, $\Delta S^{*}$, is calculated from equation 9. The enthalpy activation, $\Delta H^{*}$, and Gibbs free energy, $\Delta G^{*}$, calculated from:

$$
\begin{aligned}
& \Delta H^{*}=E_{a}-R T \\
& \Delta G^{*}=\Delta H^{*}-T \Delta S^{*}
\end{aligned}
$$

\begin{tabular}{|c|c|c|c|c|c|c|c|c|}
\hline \multirow[t]{2}{*}{ Compound $^{\mathrm{a}}$} & \multirow{2}{*}{$\begin{array}{l}\text { Decomposition } \\
\text { temperature }\left({ }^{\circ} \mathrm{C}\right)\end{array}$} & \multirow[t]{2}{*}{ Method } & \multicolumn{5}{|c|}{ Parameter } & \multirow{2}{*}{$\begin{array}{l}\text { Correlation } \\
\text { coefficient } \\
\text { (r) }\end{array}$} \\
\hline & & & $\begin{array}{c}E_{\mathrm{a}} \\
\left(\mathrm{KJ} \mathrm{mol}^{-1}\right)\end{array}$ & $\underset{\left(\mathbf{s}^{-1}\right)}{A}$ & $\begin{array}{c}\Delta S^{*} \\
\left(\mathrm{~J} \mathrm{~mol}^{-1} \mathrm{~K}^{-1}\right)\end{array}$ & $\begin{array}{c}\Delta H^{*} \\
\left(\mathrm{KJ} \mathrm{mol}^{-1}\right)\end{array}$ & $\begin{array}{c}\Delta G^{*} \\
\left(K^{\prime} \mathrm{mol}^{-1}\right)\end{array}$ & \\
\hline \multirow[t]{4}{*}{$\mathrm{HL}_{1}$} & $211-346$ & CR & 45.8 & $7.58 \times 10^{1}$ & -214 & 41.2 & 159 & 0.99221 \\
\hline & & $\mathrm{HM}$ & 53.6 & $4.18 \times 10^{2}$ & -200 & 49 & 159 & 0.99398 \\
\hline & $498-624$ & $\mathrm{CR}$ & 180 & $4.43 \times 10^{8}$ & -87.9 & 174 & 247 & 0.99355 \\
\hline & & $\mathrm{HM}$ & 193 & $6.40 \times 10^{9}$ & -65.8 & 186 & 241 & 0.99169 \\
\hline \multirow[t]{4}{*}{$\mathrm{HL}_{3}$} & $158-401$ & CR & 46.9 & $7.11 \times 10^{1}$ & -215 & 42.3 & 161 & 0.99322 \\
\hline & & $\mathrm{HM}$ & 48.4 & $1.17 \times 10^{2}$ & -210 & 43.8 & 160 & 0.99788 \\
\hline & $502-643$ & CR & 162 & $2.34 \times 10^{7}$ & -113 & 155 & 250 & 0.98442 \\
\hline & & $\mathrm{HM}$ & 173 & $2.50 \times 10^{8}$ & -92.2 & 166 & 245 & 0.99156 \\
\hline \multirow[t]{4}{*}{$\mathrm{HL}_{5}$} & $225-271$ & $\mathrm{CR}$ & 329 & $2.54 \times 10^{30}$ & 333 & 325 & 151 & 0.99453 \\
\hline & & $\mathrm{HM}$ & 338 & $1.70 \times 10^{32}$ & 367 & 333 & 142 & 0.99452 \\
\hline & $443-630$ & $\mathrm{CR}$ & 108 & $1.51 \times 10^{4}$ & -173 & 101 & 242 & 0.99432 \\
\hline & & $\mathrm{HM}$ & 120 & $2.05 \times 10^{5}$ & -152 & 113 & 236 & 0.9939 \\
\hline \multirow[t]{4}{*}{ (1) } & $142-240$ & CR & 70.9 & $5.53 \times 10^{5}$ & -139 & 67.1 & 131 & 0.99122 \\
\hline & & $\mathrm{HM}$ & 80.8 & $1.40 \times 10^{7}$ & -112 & 76.9 & 129 & 0.98595 \\
\hline & $301-418$ & $\mathrm{CR}$ & 102 & $1.31 \times 10^{6}$ & -134 & 96.5 & 181 & 0.99104 \\
\hline & & $\mathrm{HM}$ & 114 & $2.10 \times 10^{7}$ & -111 & 108 & 179 & 0.99064 \\
\hline \multirow[t]{4}{*}{ (2) } & $127-372$ & $\mathrm{CR}$ & 31.2 & $3.31 \times 10^{0}$ & -240 & 26.9 & 152 & 0.99523 \\
\hline & & $\mathrm{HM}$ & 39.2 & $3.59 \times 10^{1}$ & -220 & 34.9 & 150 & 0.98744 \\
\hline & $496-715$ & CR & 108 & $1.59 \times 10^{4}$ & -173 & 101 & 254 & 0.98712 \\
\hline & & $\mathrm{HM}$ & 119 & $5.78 \times 10^{4}$ & -163 & 112 & 255 & 0.98669 \\
\hline \multirow[t]{4}{*}{ (3) } & $189-292$ & $\mathrm{CR}$ & 106 & $3.74 \times 10^{8}$ & -85.3 & 102 & 146 & 0.99596 \\
\hline & & $\mathrm{HM}$ & 115 & $7.73 \times 10^{9}$ & -60.0 & 111 & 142 & 0.99460 \\
\hline & $349-403$ & CR & 235 & $9.36 \times 10^{16}$ & 73.5 & 230 & 182 & 0.99590 \\
\hline & & $\mathrm{HM}$ & 250 & $2.09 \times 10^{18}$ & 99.3 & 244 & 180 & 0.99435 \\
\hline \multirow[t]{4}{*}{ (4) } & $142-399$ & $\mathrm{CR}$ & 31.8 & $2.10 \times 10^{0}$ & -244 & 27.3 & 160 & 0.99161 \\
\hline & & $\mathrm{HM}$ & 41.0 & $3.60 \times 10^{1}$ & -220 & 36.5 & 156 & 0.98130 \\
\hline & $599-715$ & CR & 171 & $4.27 \times 10^{7}$ & -108 & 163 & 264 & 0.98947 \\
\hline & & $\mathrm{HM}$ & 187 & $2.01 \times 10^{8}$ & -95.4 & 179 & 268 & 0.99112 \\
\hline
\end{tabular}

The calculated values of $\mathrm{E}, \mathrm{A}, \Delta S^{*}, \Delta H^{*}$ and $\Delta G^{*}$ for the decomposition steps for ligands ( $\left.\mathrm{HL}_{\mathrm{n}}\right)$ and their complexes (1-4) are summarized in Table 5. It is clear from these results that the change of substituent strongly affects the activation thermodynamic parameters.

aNumbers as given in Table 2

Table 5: Thermodynamic parameters of the thermal decomposition of $\mathrm{HL}_{n}$ and their $\mathrm{Cu}(\mathrm{II})$ complexes. 
Citation: Abou-Dobara MI, El-Sonbati AZ, Diab MA, El-Bindary AA, Morgan SM (2014) Thermal Properties, Antimicrobial Activity of Azo Complexes and Ultrastructure Study of Some Affected Bacteria. J Microbial Biochem Technol S3: 006. doi:10.4172/1948-5948.S3-006

Page 9 of 13

\begin{tabular}{|c|c|c|c|c|c|}
\hline \multirow[t]{2}{*}{ Complex $^{a}$} & \multirow[t]{2}{*}{ Concentration } & \multicolumn{2}{|c|}{ Gram positive bacteria } & \multicolumn{2}{|c|}{ Gram negative bacteria } \\
\hline & & $\begin{array}{l}\text { Bacillus } \\
\text { cereus }\end{array}$ & $\begin{array}{c}\text { Staphylococcus } \\
\text { aureus }\end{array}$ & $\begin{array}{c}\text { Escherichia } \\
\text { coli }\end{array}$ & $\begin{array}{c}\text { Klebsiella } \\
\text { pneumoniae }\end{array}$ \\
\hline \multirow{3}{*}{ (1) } & $50 \mu \mathrm{g} / \mathrm{ml}$ & -ve & -ve & 4 & $-v e$ \\
\hline & $100 \mu \mathrm{g} / \mathrm{ml}$ & -ve & -ve & 4 & -ve \\
\hline & $150 \mu \mathrm{g} / \mathrm{ml}$ & $-v e$ & -ve & 2 & -ve \\
\hline \multirow{3}{*}{ (2) } & $50 \mu \mathrm{g} / \mathrm{ml}$ & -ve & -ve & 5 & $-v e$ \\
\hline & $100 \mu \mathrm{g} / \mathrm{ml}$ & $-v e$ & 3 & 5 & $-v e$ \\
\hline & $150 \mu \mathrm{g} / \mathrm{ml}$ & $-v e$ & 3 & 4 & $-v e$ \\
\hline \multirow{3}{*}{ (3) } & $50 \mu \mathrm{g} / \mathrm{ml}$ & 1 & 8 & 4 & $-v e$ \\
\hline & $100 \mu \mathrm{g} / \mathrm{ml}$ & 1 & 9 & 4 & $-v e$ \\
\hline & $150 \mu \mathrm{g} / \mathrm{ml}$ & 1 & 10 & 3 & -ve \\
\hline \multirow{3}{*}{ (4) } & $50 \mu \mathrm{g} / \mathrm{ml}$ & -ve & -ve & 5 & -ve \\
\hline & $100 \mu \mathrm{g} / \mathrm{ml}$ & -ve & 5 & 5 & -ve \\
\hline & $150 \mu \mathrm{g} / \mathrm{ml}$ & 2 & 5 & 4 & $-v e$ \\
\hline \multirow{3}{*}{ Penicillin } & $50 \mu \mathrm{g} / \mathrm{ml}$ & 1 & 2 & 1 & -ve \\
\hline & $100 \mu \mathrm{g} / \mathrm{ml}$ & 3 & 2 & 3 & -ve \\
\hline & $150 \mu \mathrm{g} / \mathrm{ml}$ & 3 & 2 & 3 & -ve \\
\hline
\end{tabular}

aNumbers as given in Table 2

Table 6: Antibacterial activity data of $\mathrm{Cu}(\mathrm{II})$ complexes. The results were recorded as the diameter of inhibition zone $(\mathrm{mm})$.
The complex (3) is the highest value of $\mathrm{E}_{\mathrm{a}}$. This can be attributed to the fact that the effective charge experienced by the d-electrons increases due to the electron withdrawing $\mathrm{p}$-substituent $\mathrm{NO}_{2}$ while it decreases by the electron donating character of $\mathrm{OCH}_{3}$ and $\mathrm{CH}_{3}$. This indicates that, the complex (3) is more thermally stable than the other complexes [4].

\section{Antimicrobial activity of complexes}

The antimicrobial activity of $\mathrm{Cu}(\mathrm{II})$ complexes of $\mathrm{HL}_{\mathrm{n}}$ were tested against some bacteria and fungi. More than one test organism was tested to increase the chance of detection of their antimicrobial activities. The used organisms in the present investigation included two Gram positive bacteria (B. cereus and S. aureus) and two Gram negative bacteria (E. coli and K. pneumoniae) in addition to four different kinds of fungi (A. niger, A. alternata, P. italicum and F. oxysporium).

The results of the antibacterial activity of the $\mathrm{Cu}(\mathrm{II})$ complexes of $\mathrm{HL}_{\mathrm{n}}$ (1-4) were recorded in Table 6. The complexes (1-4) have no antibacterial activity against Klebsiella pneumoniae and Bacillus cereus except complex (3) has low antibacterial activity against Bacillus cereus, while it in all used concentration was found to have high antibacterial activity against Staphylococcus aureus and Escherichia coli. Complex (4)
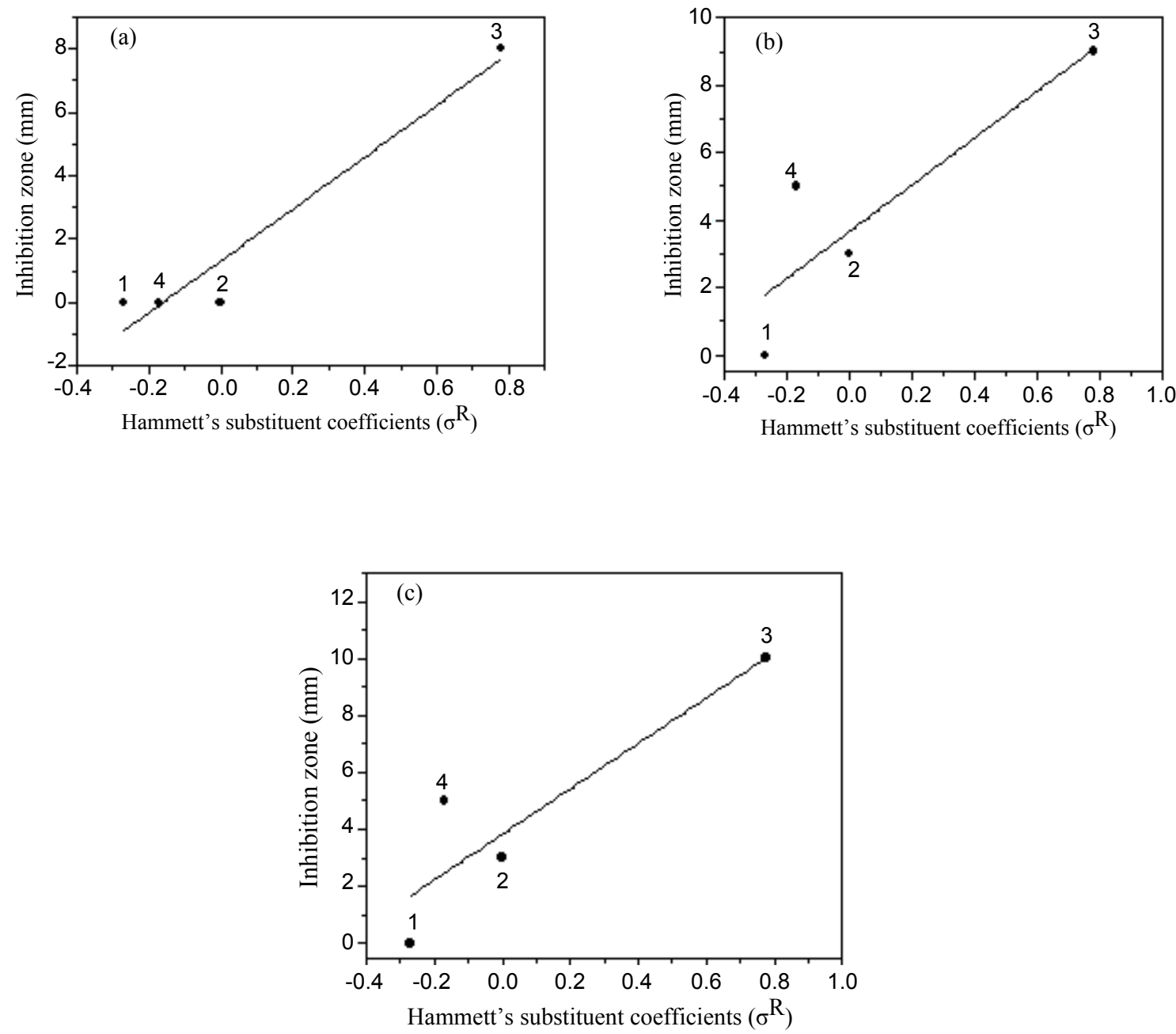

Figure 9: The relation between Hammett's substituent coefficients $\left(\sigma^{R}\right)$ versus inhibition zone $(\mathrm{mm})$ for $\mathrm{Cu}(\mathrm{II})$ complexes (In case of using concentration $a=50 \mu \mathrm{g} / \mathrm{ml}, \mathrm{b}=100 \mu \mathrm{g} / \mathrm{ml}$ and $\mathrm{c}=150 \mu \mathrm{g} / \mathrm{ml}$ against $S$. aureus). 
Citation: Abou-Dobara MI, El-Sonbati AZ, Diab MA, El-Bindary AA, Morgan SM (2014) Thermal Properties, Antimicrobial Activity of Azo Complexes and Ultrastructure Study of Some Affected Bacteria. J Microbial Biochem Technol S3: 006. doi:10.4172/1948-5948.S3-006

Page 10 of 13

was active only at concentration $=150 \mu \mathrm{g} / \mathrm{ml}$. We found that the complex $\left[\mathrm{Cu}\left(\mathrm{L}_{5}\right)(\mathrm{OAc})\left(\mathrm{OH}_{2}\right)\right] \cdot 2 \mathrm{H}_{2} \mathrm{O}(3)$ is more active than other complexes, namely $\left[\mathrm{Cu}\left(\mathrm{L}_{1}\right)(\mathrm{OAc})\left(\mathrm{OH}_{2}\right)\right] \cdot 2 \mathrm{H}_{2} \mathrm{O}(1), \quad\left[\mathrm{Cu}\left(\mathrm{L}_{3}\right)(\mathrm{OAc})\left(\mathrm{OH}_{2}\right)\right] \cdot 2 \mathrm{H}_{2} \mathrm{O}$ (2) and $\left[\mathrm{Cu}\left(\mathrm{L}_{2}\right)(\mathrm{OAc})\left(\mathrm{OH}_{2}\right)\right] \cdot 2 \mathrm{H}_{2} \mathrm{O}(4)$ against Staphylococcus aureus,

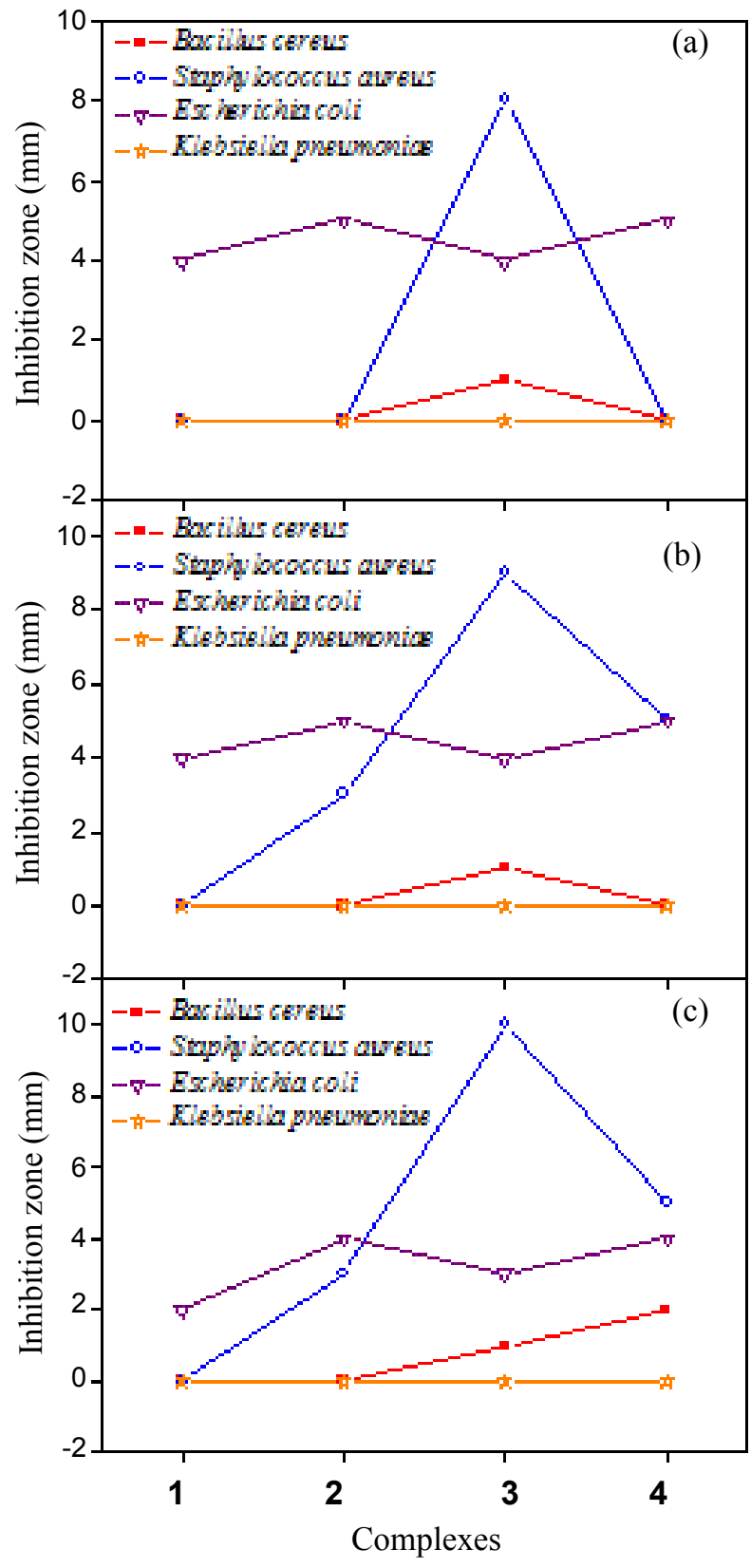

Figure 10: Comparative analysis for antibacterial activity of the $\mathrm{Cu}(\mathrm{II})$ complexes for concentration a) $=50 \mu \mathrm{g} / \mathrm{ml}, \mathrm{b})=100 \mu \mathrm{g} / \mathrm{ml}$ and $\mathrm{c})=150 \mu \mathrm{g} / \mathrm{ml}$.
Escherichia coli and Bacillus cereus and this is may be related to the nature of the p-substituent existing in the complexes. This can be attributed to the fact that the effective charge experienced by the d-electrons increased due to the electron withdrawing character of complex (3) while it decreased by the electrons donating character of complex (1). This is in accordance with that expected from Hammett's substituent coefficients $(\sigma \mathrm{R})$ as shown in Figure 9. It is clear that the values of inhibition zone $(\mathrm{mm})$ increase with increasing $\sigma \mathrm{R}$. It is important to note that the existence of a methyl and/or methoxy group enhances the electron density on the coordination sites and simultaneously decreases the values of inhibition zone. Staphylococcus aureus was affected by the complexes (2-4) (inhibition zone of complex $(2)=3$ and $3 \mathrm{~mm}$ at concentrations $=100$ and $150 \mu \mathrm{g} / \mathrm{ml}$, respectively; inhibition zone of complex $(3)=8,9$ and $10 \mathrm{~mm}$ at concentrations $=50$, 100 and $150 \mu \mathrm{g} / \mathrm{ml}$, respectively; inhibition zone of complex (4)=5 and $5 \mathrm{~mm}$ at concentration $=100$ and $150 \mu \mathrm{g} / \mathrm{ml}$, respectively). Addition to that Escherichia coli was also affected by the complexes (1-4) (inhibition zone of complex $(1)=4,4$ and $2 \mathrm{~mm}$ at concentrations $=50,100$ and 150 $\mu \mathrm{g} / \mathrm{ml}$, respectively; inhibition zone of complex $(2)=5,5$ and $4 \mathrm{~mm}$ at concentrations $=50,100$ and $150 \mu \mathrm{g} / \mathrm{ml}$, respectively; inhibition zone of complex (3) $=4,4$ and $3 \mathrm{~mm}$ at concentrations $=50,100$ and $150 \mu \mathrm{g} /$ $\mathrm{ml}$, respectively; inhibition zone of complex $(4)=5,5$ and $4 \mathrm{~mm}$ at concentrations $=50,100$ and $150 \mu \mathrm{g} / \mathrm{ml}$, respectively). The complex (3) is more active than penicillin against Staphylococcus aureus and Escherichia coli.

Comparative analysis for antibacterial study of complexes (14) is shown in Figure 10. It is observed that the complex (3) is more potent antibacterial than the other complexes. This enhancement in antibacterial activity is rationalized on the basis of the partial sharing of the positive charge of metal ions with donor groups [37,38]. This may support the argument that some type of biomolecular binding to the metal ions or interchelation or electrostatic interactions causes

\begin{tabular}{|c|c|c|c|c|c|}
\hline Complex $^{a}$ & $\begin{array}{l}\text { Concentration } \\
(\mu \mathrm{g} / \mathrm{ml})\end{array}$ & $\begin{array}{c}\text { Aspergillus } \\
\text { niger }\end{array}$ & $\begin{array}{c}\text { Fusarium } \\
\text { oxysporum }\end{array}$ & $\begin{array}{c}\text { Alternaria } \\
\text { alternata }\end{array}$ & $\begin{array}{l}\text { Penicillium } \\
\text { italicum }\end{array}$ \\
\hline \multirow{3}{*}{ (1) } & $50 \mu \mathrm{g} / \mathrm{ml}$ & $-\mathrm{ve}$ & - ve & $-v e$ & -ve \\
\hline & $100 \mu \mathrm{g} / \mathrm{ml}$ & -ve & -ve & -ve & -ve \\
\hline & $150 \mu \mathrm{g} / \mathrm{ml}$ & -ve & -ve & -ve & -ve \\
\hline \multirow{3}{*}{ (2) } & $50 \mu \mathrm{g} / \mathrm{ml}$ & 1 & -ve & 1 & -ve \\
\hline & $100 \mu \mathrm{g} / \mathrm{ml}$ & 1 & -ve & 1 & -ve \\
\hline & $150 \mu \mathrm{g} / \mathrm{ml}$ & -ve & -ve & -ve & -ve \\
\hline \multirow{3}{*}{ (3) } & $50 \mu \mathrm{g} / \mathrm{ml}$ & -ve & -ve & 1 & -ve \\
\hline & $100 \mu \mathrm{g} / \mathrm{ml}$ & -ve & -ve & 1 & -ve \\
\hline & $150 \mu \mathrm{g} / \mathrm{ml}$ & 2 & -ve & 2 & -ve \\
\hline \multirow{3}{*}{ (4) } & $50 \mu \mathrm{g} / \mathrm{ml}$ & -ve & -ve & -ve & -ve \\
\hline & $100 \mu \mathrm{g} / \mathrm{ml}$ & 3 & -ve & 2 & -ve \\
\hline & $150 \mu \mathrm{g} / \mathrm{ml}$ & 4 & -ve & 3 & -ve \\
\hline \multirow{3}{*}{ Miconazole } & $50 \mu \mathrm{g} / \mathrm{ml}$ & 1 & 2 & 5 & 1 \\
\hline & $100 \mu \mathrm{g} / \mathrm{ml}$ & 3 & 3 & 6 & 1 \\
\hline & $150 \mu \mathrm{g} / \mathrm{ml}$ & 4 & 3 & 6 & 2 \\
\hline
\end{tabular}

aNumbers as given in Table 2

Table 7: Antifungal activity data of $\mathrm{Cu}$ (II) complexes. The results were recorded as the diameter of inhibition zone $(\mathrm{mm})$.

\begin{tabular}{|l|c|c|c|c|c|}
\hline \multirow{2}{*}{ Treatment } & \multicolumn{2}{|c|}{ Escherichia coli } & \multicolumn{2}{c|}{ Staphylococcus aureus } \\
\cline { 2 - 5 } & Cell length (nm) & Cell width (nm) & Distance between cell wall and cell membrane (nm) & Cell diameter (nm) & Cell wall thickness (nm) \\
\hline Control & $474.7 \pm 30.7$ & $243.3 \pm 5.5$ & $17.6 \pm 1.9$ & $14.6 \pm 1$ \\
\hline DMF & $465.8 \pm 11.4$ & $249.3 \pm 2.8$ & $19.5 \pm 0.6$ & $274.9 \pm 18.7$ \\
\hline Complex (3) & $438.9 \pm 35$ & $252.6 \pm 3.5$ & $29.5 \pm 0.6^{*}$ & $19 \pm 1.1^{*}$ \\
\hline
\end{tabular}

'Significant different at 0.05 significance level.

Table 8: Morphometric analysis of bacterial cell treated with complex (3) 
Citation: Abou-Dobara MI, El-Sonbati AZ, Diab MA, El-Bindary AA, Morgan SM (2014) Thermal Properties, Antimicrobial Activity of Azo Complexes and Ultrastructure Study of Some Affected Bacteria. J Microbial Biochem Technol S3: 006. doi:10.4172/1948-5948.S3-006

Page 11 of 13

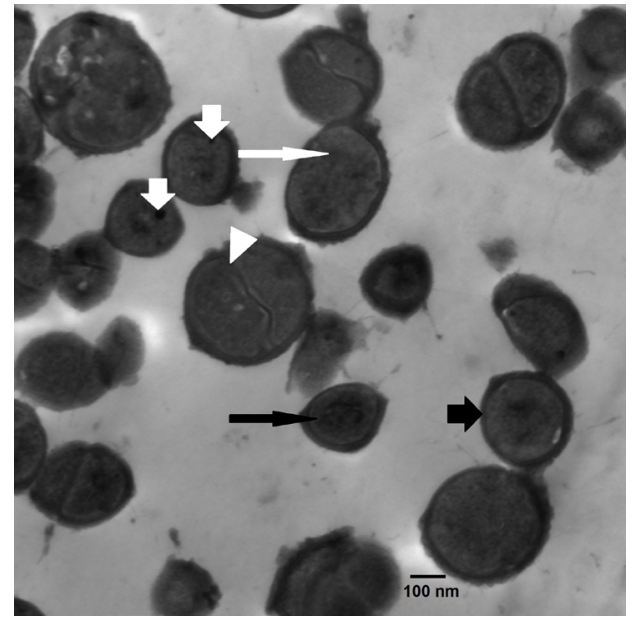

Figure 11: TEM photograph of $S$. aureus treated with DMF illustrating decreased size of cocci cells (long black arrow), Electron-dense boundary cell wall increased in thickness (short black arrow), numerous ribosomes (long white arrow), Electron-dense granules (short white arrow) and increased number of cells forming division septa (arrow head). [Specimen fixed in 4F1G solution and double stained with uranyl acetate and lead citrate, scale bar=100 $\mathrm{nm}]$.

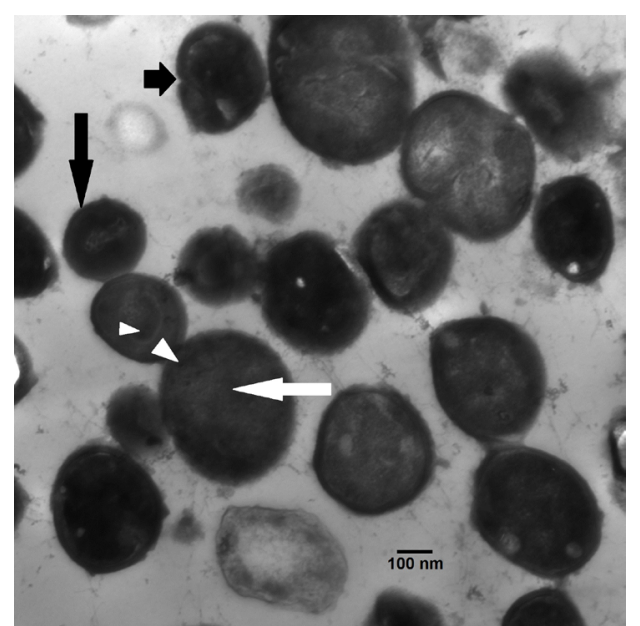

Figure 12: TEM photograph of normal $S$. aureus illustrating different size of cocci cells, normal thin Electron-dense cell walls (long black arrow), homogenous Electron-dense cytoplasm (long white arrow), normal division (short black arrow) and numerous ribosomes (arrow head). [Specimen fixed in $4 F 1 G$ solution and double stained with uranyl acetate and lead citrate, scale bar=100 nm].

the inhibition of biological synthesis. So it can be concluded that some complexes exhibits higher antimicrobial activity than the free ligand [39].

The results of the examination of antifungal activity of the complexes (1-4) were recorded in Table 7 . The results revealed that the complexes (1-4) have no antifungal activity against Fusarium oxysporum and Penicillium italicum, while they were found to have low antifungal activity against Aspergillus niger and Alternaria alternate coli.

The results of the Transmission Electronic Micrograph (TEM) comparative study on the morphology and internal ultrastuctures of normal and complex (3) treated E. coli and S. aureus; provided strong evidence that complex (3) is stressful and toxic for the bacterial cells. In general, the cytomorphic changes; in both treated E. coli and S. aureus; appears mainly in the cell wall. In the case of $S$. aureus and complex (3) as well as DMF treatments resulted in significant morphometric changes including cell size reduction and cell wall thickening as presented in Table 8. These changes enabled $S$. aureus to keep its internal components in stable condition as shown in Figure 11; under the DMF stress; similar to normal cell (Figure 12). Although DMF seems to accelerate cell division, complex (3) treated bacteria showed normal division rate in the examined field (Figure 12). This appearance may be a result to high death rate after treating with complex (3).

For complex (3) could damage some sites in the thickening cell wall as shown in Figure 13. Moreover, complex (3) treatment led to

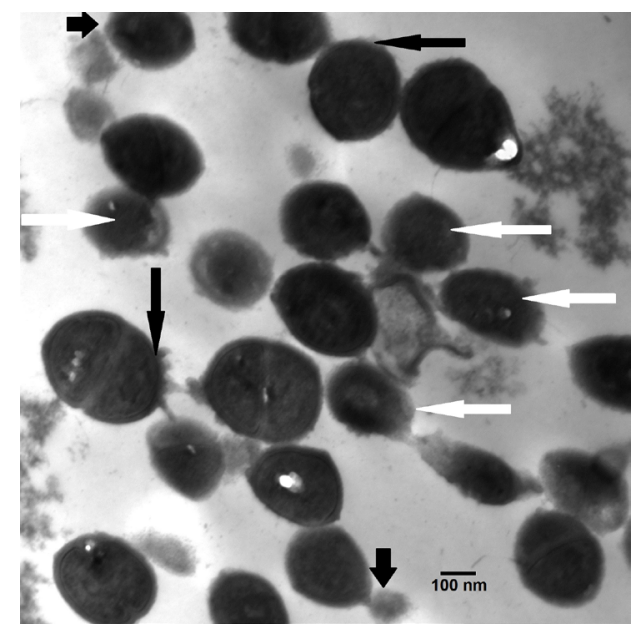

Figure 13: TEM photograph of $S$. aureus treated with complex (3) illustrating cocci cells, Electron-dense cell wall increased in thickness with some damaged sites (long black arrow), granular cell contents appear to be exuding from the damaged membrane (short black arrow) and some cells without boundary cell walls (long white arrow). [Specimen fixed in 4F1G solution and double stained with uranyl acetate and lead citrate, scale bar=100 nm].

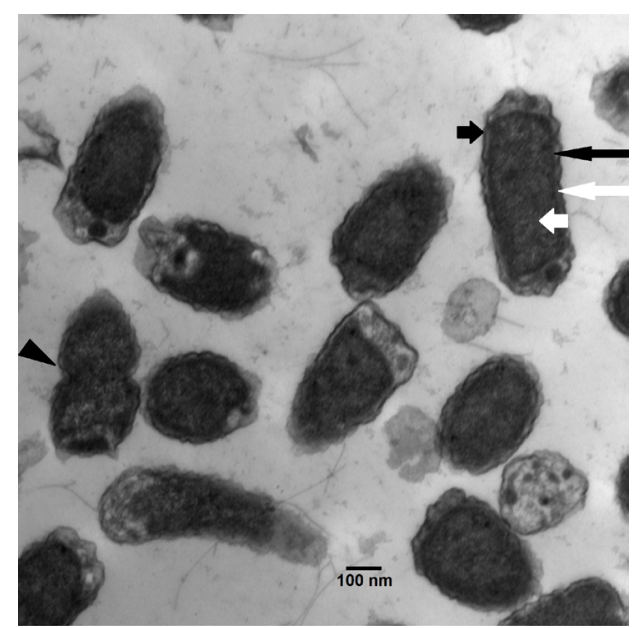

Figure 14: TEM photograph of normal $E$. coli showing rod shaped cells, normal smooth continuous cell wall (short black arrow) and cell membrane (long black arrow), homogenous Electron-dense cytoplasm (short white arrow), normal electron-lucent region between cell wall and cell membrane (long white arrow) and normal cell division (arrow head). [Specimen fixed in 4F1G solution and double stained with uranyl acetate and lead citrate, scale bar=100 nm]. 
Citation: Abou-Dobara MI, El-Sonbati AZ, Diab MA, El-Bindary AA, Morgan SM (2014) Thermal Properties, Antimicrobial Activity of Azo Complexes and Ultrastructure Study of Some Affected Bacteria. J Microbial Biochem Technol S3: 006. doi:10.4172/1948-5948.S3-006

Page 12 of 13

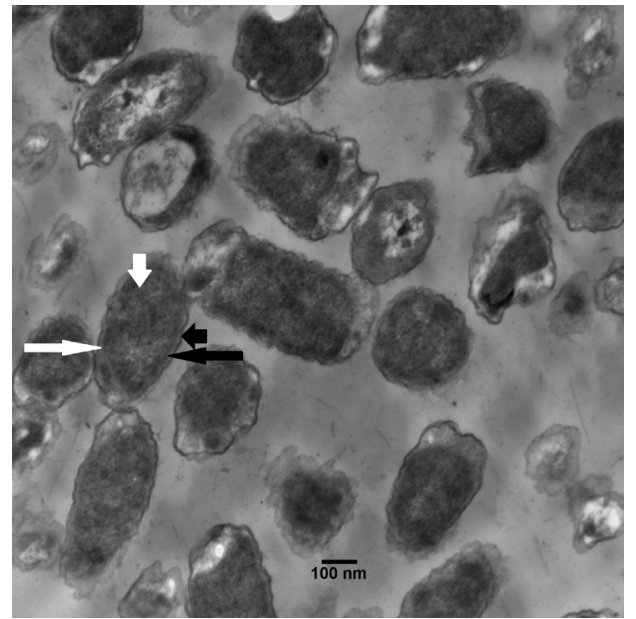

Figure 15: TEM photograph of $E$. coli treated with DMF showing rod shaped cells, normal smooth continuous cell wall (short black arrow) and cell membrane (long black arrow), homogenous Electron-dense cytoplasm (short white arrow), normal electron-lucent region between cell wall and cell membrane (long white arrow). [Specimen fixed in 4F1G solution and double stained with uranyl acetate and lead citrate, scale bar=100 nm]

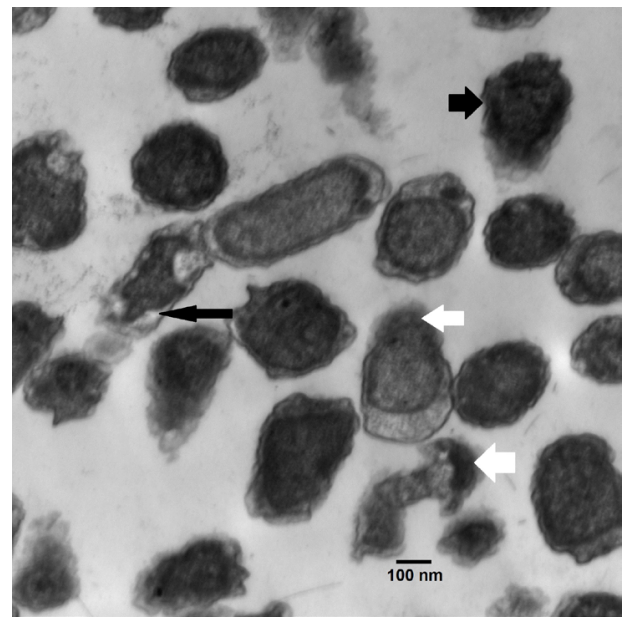

Figure 16: TEM photograph of E. coli treated with complex (3) showing rod cells with rough irregular cell wall (short black arrow), increased electron-lucent region between cell wall and cell membrane (long black arrow) and granular cell contents appear to be exuding from the damaged membrane (white arrow) [Specimen fixed in 4F1G solution and double stained with uranyl acetate and lead citrate, scale bar $=100 \mathrm{~nm}$.

completely lysis of some cell walls leaving the cell contents as spherical aggregates (Figure 13). Regarding to E. coli, DMF treatment didn't result in any significant cytomorphological as shown in Figures 14 and 15 or morphometric changes. Also, complex (3) treatment didn't result in any significant morphometric changes in the cell size (Table 8). Whereas it was found to significantly increase electron-lucent region between cell wall and cell membrane by more than $30 \%$ of its normal length (Table 8) demonstrating on detachment of the cell wall from the plasma membrane. This action appears to be sequenced by lysis of some sites in the cell wall and led to rough irregular cell wall as shown in Figure 16. In general, the final effect of complex (3) appears as granular cell contents exude from the damaged membrane (Figures
13 and 16) which confirmed that complex (3) has bactericidal effect against both bacteria.

Morphological changes of organisms under stressful conditions are the most visible parameters of bacterial adaptation. The changes in morphology as an adaptive response to adverse environmental conditions have already been reported with several bacterial species [40-43].

In the present investigation, the cell morphology of complex (3) treated cells of studied bacteria as observed by TEM indicated malformed bacteria with rough and wrinkled cell surface. Furthermore, septal region showed slight swelling due to the formation of intercalating cells.

\section{Conclusions}

The results obtained can be summarized as follows:

i. The data revealed that the coordination geometry around $\mathrm{Cu}(\mathrm{II})$ in all complexes exhibit a trans square planar by NO.

ii. It is found that the change of substituent affects the thermal properties of azodye rhodanine derivatives and their $\mathrm{Cu}(\mathrm{II})$ complexes.

iii. The biological activity of $\mathrm{Cu}(\mathrm{II})$ complexes are tested against a number of Gram-positive and Gram-negative bacteria. The results showed that some of the complexes have a well considerable activity against some of the organisms.

iv. The tested complexes have good antibacterial activity against Staphylococcus aureus and Escherichia coli and have low antifungal activity against Aspergillus niger, Fusarium oxysporium and Alternaria alternata.

v. The complex (3) is more active than other complexes (1), (2) and (4) against Staphylococcus aureus and Escherichia coli.

vi. Our results of the TEM comparative study on the morphology and internal ultrastructures, complex (3) has bactericidal effect against Staphylococcus aureus and Escherichia coli.

\section{Acknowledgement}

The authors would like to thank Prof. Dr. Nabila El-Sayed Abdel Meguid Prof. Emeritus of Cytology and Cytochemistry, Zoology Department, Faculty of Science, Alexandria University, Egypt and Miss N.F. Omar, Botany Department, Faculty of Science, Damietta University, Egypt for her help during testing antimicrobial activity.

\section{References}

1. El-Sonbati AZ, Diab MA, Belal AAM, Morgan ShM (2012) Supramolecular structure and spectral studies on mixed-ligand complexes derived from ß-diketone with azodye rhodanine derivatives. Spectrochim Acta A 99: 353360 .

2. El-Sonbati AZ, Belal AAM, El-Gharib MS, Morgan ShM (2012) Supramolecular structure, mixed ligands and substituents effect on the spectral studies of oxovanadium(IV) complexes of bioinorganic and medicinal relevance. Spectrochim Acta A 95: 627-636.

3. El-Sonbati AZ, Diab MA, El-Bindary AA, Morgan ShM (2013) Coordination chemistry of supramolecular rhodanine azodye Sulphadrugs Review Inorg Chim 404: 175-187.

4. El-Sonbati AZ, Diab MA, El-Bindary AA, Morgan ShM (2014) Supramolecula spectroscopic and thermal studies of azodye complexes. Spectrochim Acta A Mol Biomol Spectrosc 127: 310-328.

5. Diab MA, El-Sonbati AZ, El-Bindary AA, Barakat AM (2013) Supramolecular spectral studies on metal-ligand bonding of novel quinoline azodyes. Spectrochim Acta A Mol Biomol Spectrosc 116: 428-439. 
Citation: Abou-Dobara MI, El-Sonbati AZ, Diab MA, El-Bindary AA, Morgan SM (2014) Thermal Properties, Antimicrobial Activity of Azo Complexes and Ultrastructure Study of Some Affected Bacteria. J Microbial Biochem Technol S3: 006. doi:10.4172/1948-5948.S3-006

6. Shoair AF, El-Bindary AA, El-Sonbati AZ, Younes RM (2001) Stereochemistry of new nitrogen containing heterocyclic aldehyde. VI. Novel structural and properties models of uranyl with quinoline azodyes. Spectrochim Acta A Mol Biomol Spectrosc 57: 1683-1691.

7. El-Sonbati AZ, Al-Sarawy AA, Moqbel M (2009) Polymer complexes: XLIXSupramolecular modeling of bonding in novel rare earth polymeric rhodanine drug complexes. Spectrochim Acta A Mol Biomol Spectrosc 74: 463-468.

8. Alfonso GG, Ariza JLG (1981) Derivatives of rhodanine as spectrophotometric analytical reagents: I. Condensation at $\mathrm{C}-5$ with aromatic pyridine and nonpyridine aldehydes. Microchem J 26: 574-585.

9. Stephen WI, Townshend A (1965) Some derivatives of rhodanine as analytical reagents. Analytica Chim Acta 33: 257-265.

10. El-Bindary AA, El-Sonbati AZ, El-Mossalamy EH, El-Sanatawy EM (2001) Thermodynamics of substituted pyrazolone IX: Potentiometric, spectrophotometric and conductometeric studies of 4-(4-chlorophenylazo)-3methyl-1-[2-hydroxy-3- morphilinoropanel-yl]-2-pyrazolin-5-one and its metal complexes. Spectrochim Acta A 57: 2359-2365.

11. El-Sonbati AZ, El-Bindary AA, Ahmed RM (2003) Potentiometric and conductometric studies on the complexes of some rare earth metals with rhodanine azosulfonamide derivatives XII J Soln Chem 32: 617-623.

12. Fabretti AC, Peyronel G (1977) Silver(I) and Gold(I)complexes of rhodanine. Transition Met. Chem. 2: 224-227.

13. Shehatta I, El-Bindary AA (1994) Thermodynamics of substituted rhodanine Part 1. Temperature, medium and substituent effects on the dissociation constants of 3-benzamidorhodanine and its substituted derivatives. Thermochim. Acta 237: 357-368.

14. Abou-Dobara MI, El-Sonbati AZ, Morgan ShM (2013) Influence of substituent effects on spectroscopic properties and antimicrobial activity of 5-(4'-substituted phenylazo)-2-thioxothiazolidinone derivatives. World J Microbiol Biotechnol 29 : 119-126.

15. El-Bindary AA, El-Sonbati AZ (2000) Synthesis and properties of complexes of Copper(II), Nickel(II), Cobalt(II) and Uranyl ions with 3-(P-tolylsulphonamido) rhodanine. Polish J Chem 74: 615-620.

16. Havrylyuk D, Mosula L, Zimenkovsky B, Vasylenko O, Gzella A, et al. (2010) Synthesis and anticancer activity evaluation of 4-thiazolidinones containing benzothiazole moiety. Eur J Med Chem 45: 5012-5021.

17. Moorthy BT, Ravi S, Srivastava M, Chiruvella KK, Hemlal H, et al. (2010) Nove rhodanine derivatives induce growth inhibition followed by apoptosis. Bioorg Med Chem Lett 20: 6297-6301.

18. Sudo K, Matsumoto Y, Matsushima M, Fujiwara M, Konno K, et al. (1997) Novel hepatitis $C$ virus protease inhibitors: thiazolidine derivatives. Biochem Biophys Res Commun 238: 643-647.

19. Enchev V, Chorbadjiev S, Jordanov B (2002) Comparative study of the structure of rhodanine, isorhodanine, thiazolidine-2,4-dione, and thiorhodanine. Chem Heterocycl Comp 38: 1110-1120.

20. Selwood PW (Not mentioned) Magnetic Chemistry, Interscience Pub. Inc., New York, 195.

21. Frisch MJ, Trucks GW, Schlegel HB, Scuseria GE, Robb MA, et al. (2004) Gaussian 03, Revision C.01,Gaussian, Inc., Wallingford CT.

22. Fukui K (1970) Theory of Orientation and Stereoselection. Vol. 15/1, Springer Berlin Heidelberg, p. 1.

23. El-Bindary AA, El-Sonbati AZ, Diab MA, El-Katori EE, Seyam HA (2014) Potentiometric and thermodynamic studies of some Schiff base derivatives of 4-aminoantipyrine and their metal complexes. Intern. J Adv Res 2 4: 93-502.

24. Parr RG, Yang W (Ed.) (1989), Density-Functional Theory of Atoms and Molecules, Oxford, New York.
25. El-Sonbati AZ, Diab MA, El-Bindary AA, Nozha SG (2011) Structural and characterization of novel copper(II) azodye complexes. Spectrochim Acta A Mo Biomol Spectrosc 83: 490-498.

26. Diab MA, El-Bindary AA, El-Sonbati AZ, Salem OL (2012) Supramolecula structure and substituents effect on the spectral studies of dioxouranium(VI) azodyes complexes. J Mol Struct 1007: 11-19.

27. Diab MA, El-Bindary AA, El-Sonbati AZ, OL Salem (2012) Supramolecula structure and substituents effect on the spectral studies of oxovanadium(IV) azodyes complexes. J Mol Struct 1018: 176-184.

28. Dean JA (1992) Lange`s Handbook of Chemistry, 14th ed., Megraw-Hill, New York, p.35.

29. El-Sonbati AZ, Belal AAM, Abd El-Meksoud SA, El-Boz RA (2012) Supramolecular Structure, Stereochemistry and Substituents Effect on the Spectral Studies of novel ruthenium Complexes. J Mol Struct 1027: 200-206.

30. Abd-Elrahman MI, Abdel-Latief AY, Khafagy RM, Younis N, Hafiz MM (2014) Effect of the film thickness on the optical constants and dispersion parameters of chalcogenide Ge20Se70Ag10 thin film. Mater. Sci. Semicond. Proc. 24: 21-25.

31. Zeyada HM, El-Ghamaz NA, Gaml EA (2013) Effect of substitution group variation on the optical functions of -5-sulfono-7-(4-x phenyl azo)-8-hydroxy quinoline thin films. Current Applied Physics 13: 1960-1966.

32. Basavaraja S, Balaji DS, Bedre MD, Raghunandan D, Swamy PMP, Venkataraman A (2011) Solvothermal synthesis and characterization of acicular a-Fe2O3 nanoparticles. Bull Mater Sci 34: 1313-1317.

33. Velumani S, Mathew X, Sebastian PJ (2003) Structural and optical characterization of hot wall deposited CdSexTe1-x films. Solar Energy Mater. Solar Cells 76: 359-368.

34. El-Ghamaz NA, El-Sonbati AZ, Diab MA, El-Bindary AA, Awad MK, Morgan ShM (2014) Dielectrical, conduction mechanism and thermal properties of rhodanine azodyes. Mater Sci Semicond Proc 19: 150-162.

35. Coats AW, Redfern JP (1964) Kinetic parameters from thermogravimetric data Nature 20: 68-79.

36. Horowitz HW, Metzger G (1963) A New Analysis of Thermogravimetric Traces Anal Chem 35: 1464-1468.

37. Dharmaraj N, Viswanathamurthi P, Natarajan K (2001) Ruthenium(II) complexes containing bidentate Schiff bases and their antifungal activity. Trans Met Chem 26: 105-109.

38. Chohan ZH, Khan KM, Supuran CT (2004) Synthesis of antibacterial and antifungal cobalt (II), copper (II), nickel (II) and zinc (II) complexes with bis(1, 1'-disubstituted ferrocenyl) thiocarbohydrazone and bis-(1, 1'-disubstituted ferrocenyl) carbohydrazone. Appl Organomet Chem 18: 305-310.

39. Panchal PK, Parekh HM, Pansuriya PB, Patel MN (2006) Bactericidal activity of different oxovanadium(IV) complexes with Schiff bases and application of chelation theory. J Enzyme Inhib Med Chem 21: 203-209.

40. Hanif M, Chohan ZH (2013) Design, spectral characterization and biological studies of transition metal(II) complexes with triazole Schiff bases. Spectrochim Acta A Mol Biomol Spectrosc 104: 468-476.

41. O'Hara GW, Glenn AR (1994) The adaptive acid tolerance response in root nodule bacteria and Escherichia coli. Arch Microbiol 161: 286-292.

42. Ritz M, Tholozan JL, Federighi M, Pilet MF (2001) Morphological and physiological characterization of Listeria monocytogenes subjected to high hydrostatic pressure. Appl Environ Microbiol 67: 2240-2247.

43. Neumann G, Veeranagouda Y, Karegoudar TB, Sahin O, Mäusezahl I, et al. (2005) Cells of Pseudomonas putida and Enterobacter sp. adapt to toxic organic compounds by increasing their size. Extremophiles 9: 163-168.
This article was originally published in a special issue, Bacteria: Biochemical Physiology handled by Editor. Prof. Cheorl-Ho KIM, Sungkyunkwan University, Korea 